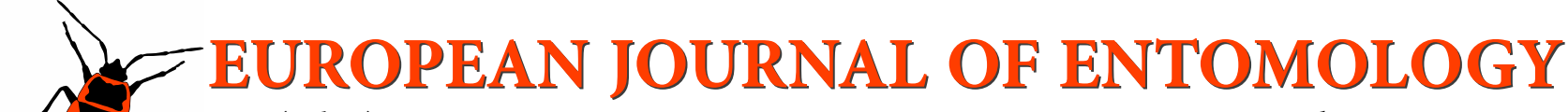 \\ ISSN (online): 1802-8829 \\ http://www.eje.cz \\ Eur. J. Entomol. 113: 279-294, 2016 \\ doi: 10.14411/eje.2016.035 \\ ORIGINAL ARTICLE
}

\section{A case study of Heleomyzidae (Diptera) recorded on snow in Poland with a review of their winter activity in Europe}

\author{
AgnieszKa SOSZYŃSKA-MAJ ${ }^{1}$ and ANDRZEJ J. WOŹNICA ${ }^{2}$ \\ ${ }^{1}$ Department of Invertebrate Zoology and Hydrobiology, University of Łódź, Banacha 12/16, 90-237 Łódź, Poland; \\ e-mail: agasosz@biol.uni.lodz.pl \\ ${ }^{2}$ Institute of Biology, Wrocław University of Environmental and Life Sciences, Kożuchowska 5b, 51-631 Wrocław, Poland; \\ e-mail: andrzej.woznica@up.wroc.pl
}

Key words. Diptera, Heleomyzidae, Europe, Poland, winter activity, snow fauna, phenology, review

\begin{abstract}
Twenty eight species of winter-active Heleomyzidae were collected during a long-term study in Poland. More than 130 samples of insects, including Heleomyzidae, were collected from the surface of snow in lowland and mountain areas using a semi-quantitative method. Lowland and mountain assemblages of Heleomyzidae recorded on snow were quite different. Heleomyza modesta (Meigen, 1835) and Scoliocentra (Leriola) brachypterna (Loew, 1873) dominated in the mountains, Tephrochlamys rufiventris (Meigen, 1830) mainly in the lowlands and Heteromyza rotundicornis (Zetterstedt, 1846) was common in both habitats. Heleomyzidae were found on snow during the whole period of snow cover, but the catches peaked from late November to the beginning of February. In late winter and early spring the occurrence of heleomyzids on snow decreased. Most individuals were active on snow at air temperatures between -2 and $+2.5^{\circ} \mathrm{C}$. A checklist of 78 winter active European Heleomyzidae is presented. Helomyza nivalis Wahlgren, 1918 is herein considered as a new junior synonym of Helomyza caesia Meigen, 1830, syn. n.
\end{abstract}

ZooBank Article LSID: 4C762D80-2771-44AA-8A15-23275096DA86

\section{INTRODUCTION}

Heleomyzidae, a small family of Diptera, comprises 151 species in Europe (Lo Giudice \& Woźnica, 2013; Woźnica, 2013). It is widely distributed around the world, but is especially numerous in areas with a cool, temperate climate (Woźnica, 2008). Many representatives of this family, especially from the tribe Heleomyzini, are cold-adapted and have a typical boreo-alpine distribution, being abundant in mountains and the north of Europe. Heleomyzid flies are one of the most common groups of insects active in winter and are often recorded on the surface of snow in Poland (Soszyńska, 2004; Soszyńska-Maj \& Woźnica, 2012) and Scandinavia (Hågvar \& Greve, 2003). In the warmer areas of southern Europe they are active at low temperatures, mostly in autumn and winter, at higher altitudes (above 1,000 m a.s.1.) or in caves (Erhard \& Spötl, 2010).

Diptera dominate the fauna in cold regions (Oliver, 1968), at high altitudes or in caves (Jefferson, 1983; Weber \& Weber, 2013). Most snow-active flies belong to five dipteran families, which are definitely the best adapted for activity at low temperatures and are recorded on snow: Trichoceridae (e.g. Hågvar \& Krzemińska, 2008), Chironomidae (Koshima, 1984, 1985; Anderson et al., 2013; Giłka et al., 2013; Soszyńska-Maj et al., 2016), Limoni- idae (Hågvar, 1971, 1976), Heleomyzidae and Sphaeroceridae (Hågvar \& Greve, 2003; Soszyńska-Maj \& Woźnica, 2012). Apart from flies, springtails (Collembola), snow scorpionflies (Mecoptera: Boreidae), spiders (Araneae), ice crawlers (Grylloblattidae), beetles (Coleoptera), psyllids (Psylloidea), bugs (Heteroptera), earwigs (Dermaptera) and even moths (Lepidoptera) belong to the assemblage of snow-active insects (Aitchison, 2001; Hågvar, 2001, 2007, 2010; Hågvar \& Aakra, 2006; Soszyńska-Maj, 2008; Jaskuła \& Soszyńska-Maj, 2011; Soszyńska-Maj \& Buszko, 2011; Soszyńska-Maj \& Jaskuła, 2013). Winteremerging aquatic insects are regularly observed on snow and are a significant subgroup within this community, with stoneflies (Plecoptera) and caddisflies (Trichoptera) being the most abundant members besides Chironomidae (Bouchard et al., 2009; Hågvar, 2010; Soszyńska-Maj, pers. observ.).

Best adapted to snow activity are brachypterous or apterous insects belonging to the genera Boreus (Mecoptera), Chionea (Diptera: Limoniidae) and Diamesa (Diptera: Chironomidae). Their morphological adaptations include enlargement of the legs for walking instead of flying, melanism, size reduction and hairy bodies (Hermann et al., 1987; Lencioni, 2004; Giłka et al., 2013). Heleomyzidae 


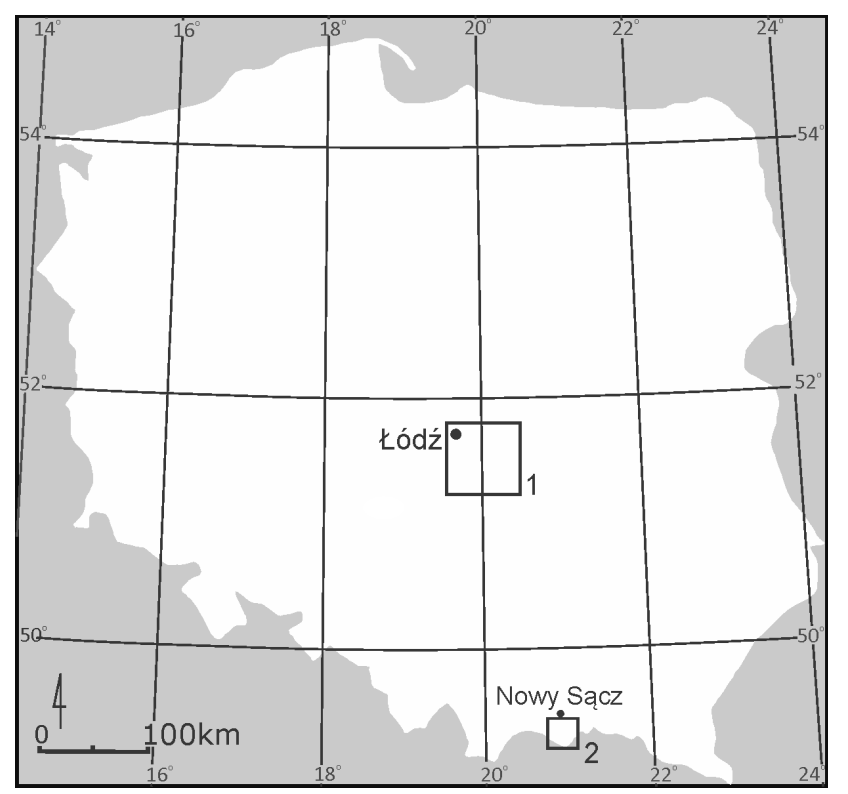

Fig. 1. Map of Poland showing the location of the sites studied: 1 central Poland (lowland), 2 - Beskid Sądecki Mountains.

do not show any morphological adaptions to snow activity, but they are adapted to low temperatures. Adults of Scoliocentra nigrinervis had the second lowest supercooling point of snow-active insects studied (mean $-16.5^{\circ} \mathrm{C}$, range $\left.-20.5 /-13^{\circ} \mathrm{C}\right)$ (Sømme \& Østbye, 1969). The lowest supercooling point was reported for the chironomid Diamesa mendotae Muttkowski $\left(-21.6^{\circ} \mathrm{C}\right)$ (Bouchard et al., 2006). It is noteworthy that some flies can survive even long, severe and snowy winters as immature stages: for example, larvae of Heleomyza borealis, a snow-active fly especially widely distributed in the Arctic, can survive temperatures as low as $-60^{\circ} \mathrm{C}$ and need a lower than $-15^{\circ} \mathrm{C}$ temperature stimulus and thereafter warmer period to pupate (Block, 2002). Despite the known low temperature preferences of the species of this family, snow-recorded Heleomyzidae have been intensively studied only by Hågvar \& Greve (2003). During an almost 20-year-long study in southern Norway, they found Heleomyzidae to be the dominant brachyceran family among the Diptera recorded on snow and identified 13 species of these flies. Four heleomyzid species were observed on snow in southern Finland (Frey, 1913), one in central Finland (Tahvonen, 1942) and two in mountain areas in Bulgaria (Czerny, 1930). The snow activity of Heleomyzidae was recorded in central Poland (Soszyńska, 2004). Von der Dunk (2006), in his work on Bavarian heleomyzids, noted 10 heleomyzids species on snow. Finally, seven species were recorded from the European part of Russia (Pavlov, 2006).

Winter activity has until now been studied only in Germany; however, the appearance on snow was not studied. Nine species of Heleomyzidae were found by Broen \&
Mohrig (1965), and 27 species were caught using various collecting methods by Bährmann \& Adaschkiewitz (2003). Twenty five species of winter-active heleomyzids were recorded in Germany using seven sampling methods, such as sweep nets, pitfall traps, Moericke traps (yellow pan traps) and cave traps (Bährmann, 1996). However, in these papers no information on snow cover was provided.

Although the snow and winter activity of Heleomyzidae are frequently discussed, no comprehensive research including quantitative or statistical analyses has been published to date. The main aim of this study was to describe the structure of the heleomyzid community recorded on snow in Poland, to compare the heleomyzid assemblage recorded on snow in the Polish lowlands and mountains, determine what influence particular weather conditions have on the winter activity of Heleomyzidae in the study area and present a checklist of winter-active Heleomyzidae in Europe.

\section{MATERIAL AND METHODS}

This investigation was carried out from 1997 to 2013, with different intensities of sampling in different years from November to the first half of April, depending on the weather and presence of snow cover. This was part of a more general, long-term research project on snow-active invertebrates in Poland. Depending on favourable atmospheric conditions samples were collected regularly, at 10 or 14 day intervals. The lowland assemblage was studied in central Poland at regular intervals in 1999-2003 and 2005-2007. The assemblage in the Beskid Sądecki Mountains (mountain community) was sampled regularly over three winter seasons 2010-2013. Other samples were collected intermittently in different years and at different localities. Only samples containing at least one heleomyzid were included in the present analysis.

The material was collected at 24 sites in central Poland (Figs 1, 2C) and at 15 sites in the Beskid Sądecki Mountains (Figs 1, 2A, $\mathrm{B}, \mathrm{D}, \mathrm{E})$. Additional data come from isolated samples collected in the Tatra, Gorce, Bieszczady and Bialskie Mountains and the Polish uplands.

All study sites in central Poland, with the highest point of 284 $\mathrm{m}$ a.s.l., were located in large forests, mostly protected as Nature Reserves (e.g. Fig. 2C). Several forest associations, such as mixed deciduous forest with fir, beech and spruce, mixed coniferous forest, riparian forest (Circeo-Alnetum), acidophilous beech woods (Luzulo pilosae-Fagetum) and dry-ground forest (TilioCarpinetum), are characteristic of this part of Poland. The Beskid Sądecki is a mountain range in the western Carpathians with the highest peak $1262 \mathrm{~m}$ a.s.l. The study areas were situated in the lower montane forest zone at altitudes of 650-750 m, covered with stands of beech with some fir and spruce (Dentario glandulosae-Fagetum) (Fig. 2A, B, D). The climates in the regions studied is presented in Table 1 (Liszewski, 2001; Durło, 2003).

A total of 131 samples of Heleomyzidae were collected on snow: 51 samples from snow in the lowlands, 64 in the Beskid Sądecki Mountains and 16 from the other study sites. The insects were picked off the snow surface by hand or with tweezers. The

Table 1. Climate in the regions studied based on Liszewski (2001) and Durło (2003).

\begin{tabular}{|c|c|c|c|c|c|}
\hline & $\begin{array}{l}\text { Average annual } \\
\text { air temperature }\end{array}$ & Snowfall & $\begin{array}{l}\text { Duration of snow } \\
\text { cover (per year) }\end{array}$ & $\begin{array}{l}\text { Average thickness } \\
\text { of snow cover }\end{array}$ & $\begin{array}{l}\text { Maximum thickness } \\
\text { of snow cover }\end{array}$ \\
\hline Cen & $+7.6-8.0^{\circ} \mathrm{C}$ & ca 70 & 40-45 days & $8-18 \mathrm{~cm}$ & $40 \mathrm{~cm}$ \\
\hline Beskid Sądecki 600-1100 m & $+4.5^{\circ} \mathrm{C}$ & ca 70 days a year & 130 days & ca $30-35 \mathrm{~cm}$ & $60 \mathrm{~cm}$ (locally $100 \mathrm{~cm}$ ) \\
\hline
\end{tabular}



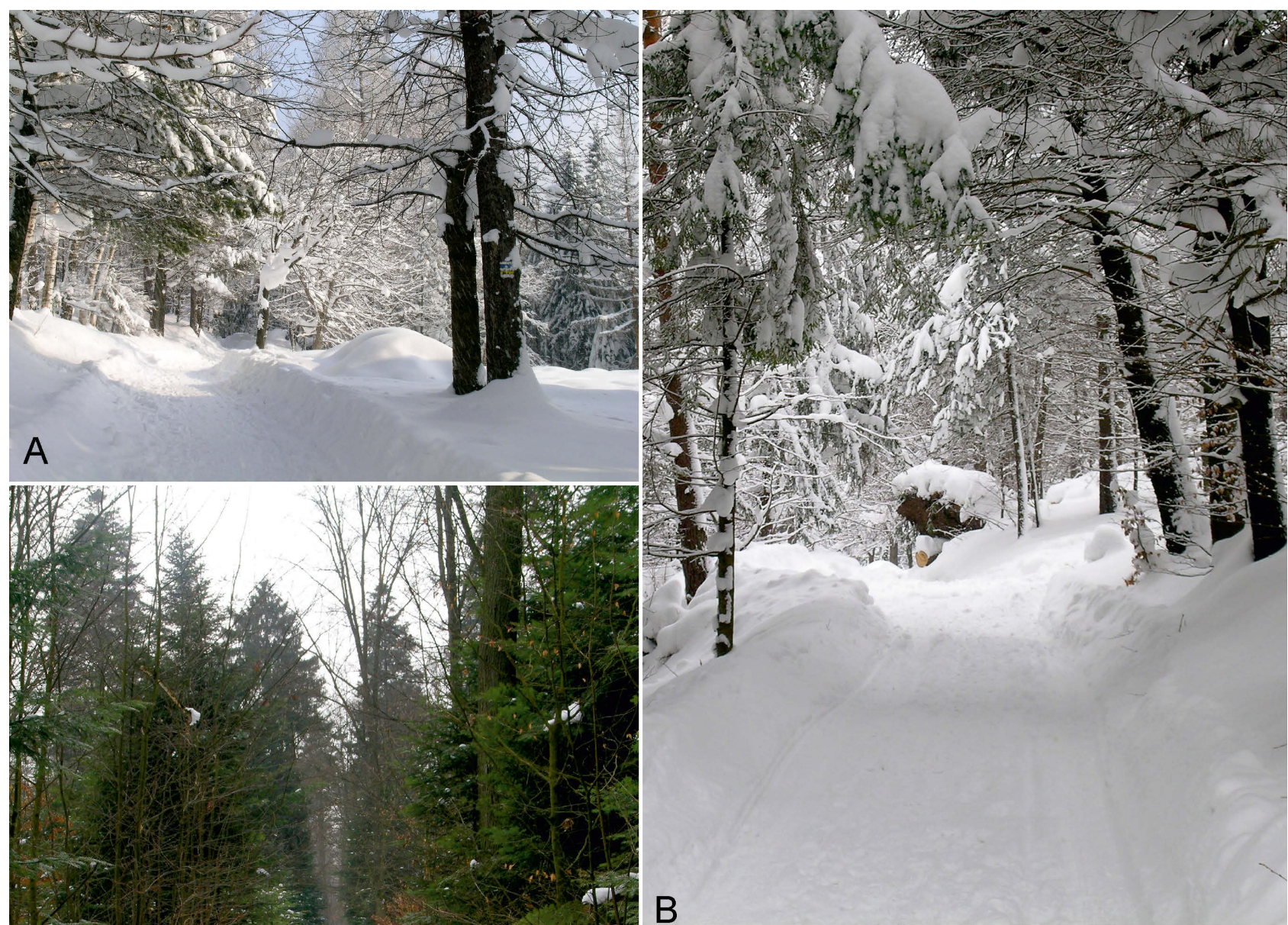

\section{A}
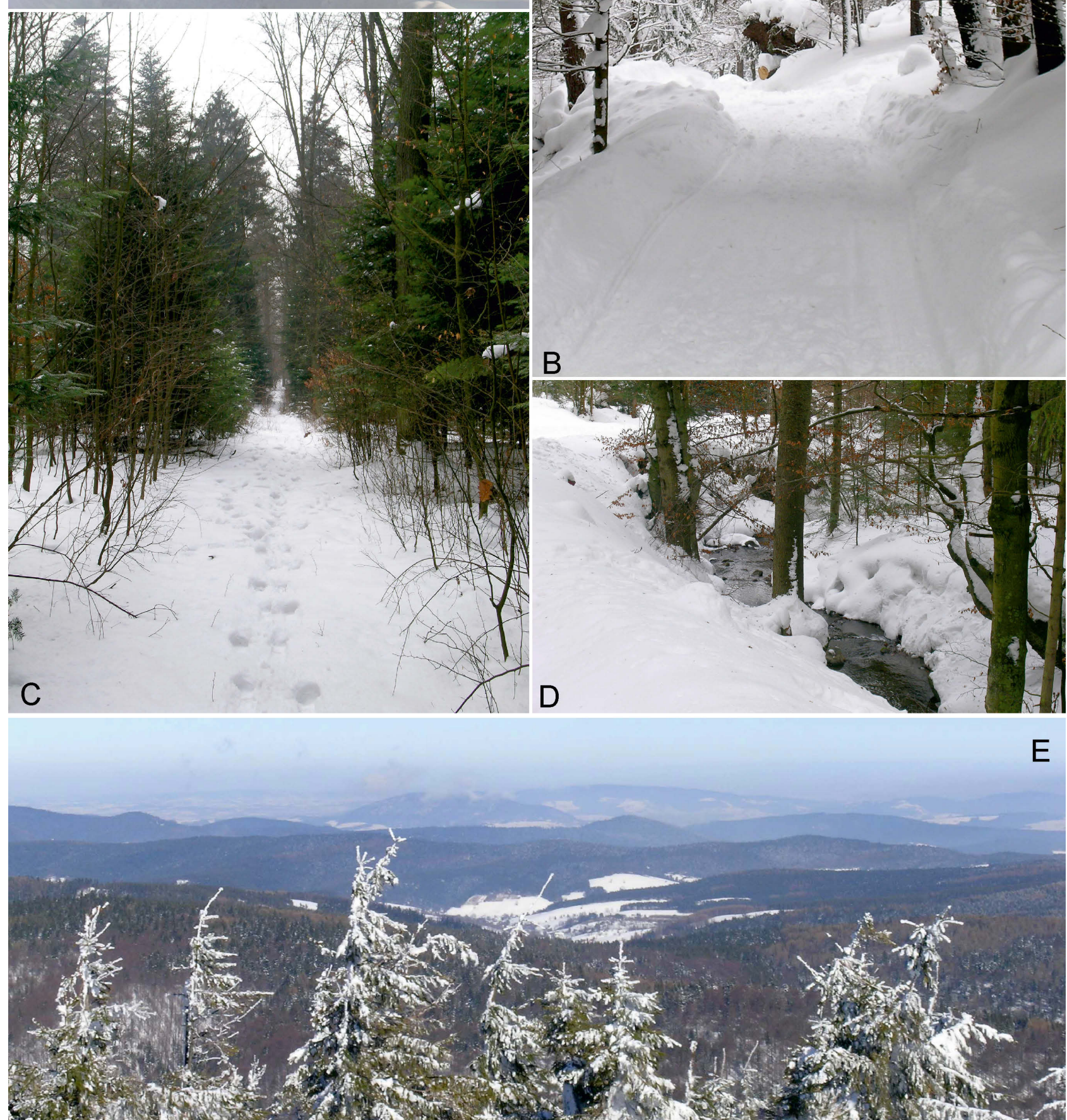

Fig. 2. Photographs taken at the sites studied. A, B, D, E - mountain forest in the Beskid Sądecki area (A - Parkowa Mountain, B - Jaworzyna Krynicka, D - Czarny Potok River, E - Beskid Sądecki Mountains); C - Molenda nature reserve in central Poland lowland. 
Table 2. List of Heleomyzidae recorded on snow in Poland, with data on the number of individuals and biocenotic indices: $D$ - dominance, F - frequency, Q - ecological significance; L - lowlands, BSM - Beskid Sądecki Mountains, M - other Polish mountains.

\begin{tabular}{|c|c|c|c|c|c|c|c|c|c|c|}
\hline No. & Species & Indiv. & $\hat{0}$ & 우 & $\mathrm{L}$ & BSM & $\mathrm{M}$ & $\mathrm{D}$ & $\mathrm{F}$ & Q \\
\hline & HELEOMYZINAE & & & & & & & & & \\
\hline 1 & Eccoptomera longiseta Loew, 1862 & 4 & 2 & 2 & 4 & & & 0.98 & 3.05 & 1.73 \\
\hline 2 & Eccoptomera obscura (Meigen, 1830) & 38 & 15 & 23 & 34 & 3 & & 9.31 & 11.45 & 10.33 \\
\hline 3 & Eccoptomera ornata Loew, 1862 & 3 & & 3 & 3 & & & 0.74 & 1.53 & 1.06 \\
\hline 4 & Eccoptomera pallescens (Meigen, 1830) & 1 & 1 & & 1 & & & 0.25 & 0.76 & 0.43 \\
\hline 5 & Gymnomus caesius (Meigen, 1830) & 18 & 9 & 9 & 1 & 8 & 5 & 4.41 & 10.69 & 6.87 \\
\hline 6 & Gymnomus spectabilis (Loew, 1862) & 3 & & 3 & & 3 & & 0.74 & 2.29 & 1.3 \\
\hline 7 & Heleomyza (Heleomyza) captiosa (Gorodkov, 1962) & 13 & 7 & 6 & & 16 & & 3.19 & 6.87 & 4.68 \\
\hline 8 & Heleomyza modesta (Meigen, 1835) & 64 & 45 & 19 & & 55 & 7 & 15.69 & 28.24 & 21.05 \\
\hline 9 & Morpholeria (Spanoparea) kerteszii Czerny, 1924 & 1 & & 1 & & 0 & 1 & 0.25 & 0.76 & 0.43 \\
\hline 10 & Oldenbergiella brumalis Czerny, 1924 & 17 & 7 & 10 & 11 & 4 & & 4.17 & 7.63 & 5.64 \\
\hline 11 & Orbellia cuniculorum Robineau-Desvoidy, 1830 & 6 & 3 & 3 & 6 & & & 1.47 & 0.76 & 1.06 \\
\hline 12 & Orbellia hiemalis (Loew, 1862) & 11 & 5 & 6 & 11 & & & 2.7 & 3.05 & 2.87 \\
\hline 13 & Orbellia myiopiformis Robineau-Desvoidy, 1830 & 8 & 3 & 7 & 5 & 3 & & 1.96 & 3.82 & 2.74 \\
\hline 14 & Schroederella iners (Meigen, 1830) & 1 & 1 & & 1 & & & 0.25 & 0.76 & 0.43 \\
\hline 15 & Scoliocentra (Leriola) brachypterna (Loew, 1873) & 61 & 26 & 33 & & 58 & 3 & 14.95 & 15.27 & 15.11 \\
\hline 16 & Scoliocentra (Leriola) nigrinervis (Wahlgren, 1918) & 7 & 4 & 3 & & 5 & 2 & 1.72 & 5.34 & 3.03 \\
\hline \multirow[t]{2}{*}{17} & Scoliocentra (Scoliocentra) villosa (Meigen, 1830) & 5 & 3 & 2 & 1 & 4 & & 1.23 & 3.82 & 2.16 \\
\hline & HETEROMYZINAE & & & & & & & & & \\
\hline 18 & Heteromyza atricornis Meigen, 1830 & 5 & 1 & 4 & & 5 & & 1.23 & 2.29 & 1.68 \\
\hline 19 & Heteromyza rotundicornis (Zetterstedt, 1846) & 60 & 40 & 20 & 28 & 32 & & 14.71 & 17.56 & 16.07 \\
\hline 20 & Tephrochlamys flavipes (Zetterstedt, 1838) & 14 & 1 & 13 & 14 & & & 3.43 & 2.29 & 2.8 \\
\hline 21 & Tephrochlamys rufiventris (Meigen, 1830) & 57 & 40 & 17 & 53 & 3 & 1 & 13.97 & 20.61 & 16.97 \\
\hline \multirow[t]{2}{*}{22} & Tephrochlamys tarsalis (Zetterstedt, 1847) & 1 & 1 & & 1 & & & 0.25 & 0.76 & 0.43 \\
\hline & SUILLIINAE & & & & & & & & & \\
\hline 23 & Suillia cepelaki Martinek, 1985 & 2 & 2 & & & 0 & 2 & 0.49 & 1.53 & 0.87 \\
\hline 24 & Suillia pallida (Fallen, 1820) & 2 & 1 & 1 & 2 & & & 0.49 & 1.53 & 0.87 \\
\hline 25 & Suillia parva (Loew, 1862) & 2 & & 2 & & 2 & & 0.49 & 1.53 & 0.87 \\
\hline 26 & Suillia ustulata (Meigen, 1830) & 2 & 2 & & 2 & & & 0.49 & 1.53 & 0.87 \\
\hline \multirow[t]{2}{*}{27} & Suillia vaginata (Loew, 1862) & 2 & 2 & & 2 & & & 0.49 & 1.53 & 0.87 \\
\hline & TOTAL & 408 & 221 & 187 & 180 & 201 & 21 & & & \\
\hline
\end{tabular}

air temperature and humidity was measured. A thermo-hygrometer was installed in the shade, about $1 \mathrm{~m}$ above the ground. Only live flies were collected from the snow. The time spent collecting was limited (up to $1.5 \mathrm{~h}$ ) so that the samples could be compared semi-quantitatively.

Specimens were also collected using pitfall traps, which caught ground-active invertebrates, under snow cover in the lowland area. Heleomyzidae were caught using this method only in winter 2005/2006 on xerothermic wasteland and in marshy meadows every two weeks. The traps were constructed as described by Aitchison (1974) and in more detail by Soszyńska-Maj \& Jaskuła (2013). They contained ethylene glycol (freezing point: $-30^{\circ} \mathrm{C}$ ) to preserve the insects with addition of a small amount of detergent to reduce surface tension. They were protected with a roof against snow and rain. These samples, together with qualitative samples

Table 3. Heleomyzidae collected in central Poland using pitfall traps when there was no snow; $\mathrm{X}$ - xerothermic wasteland, WM - marshy meadow.

\begin{tabular}{|c|c|c|c|c|c|c|}
\hline \multirow{2}{*}{ Species } & \multirow{2}{*}{$\begin{array}{l}1-15 \\
\text { Nov. }\end{array}$} & \multirow{2}{*}{$\begin{array}{c}16-30 \\
\text { Nov. }\end{array}$} & \multirow{2}{*}{$\begin{array}{l}1-15 \\
\text { Dec. }\end{array}$} & \multicolumn{2}{|c|}{ 16-31 15-31 } & \\
\hline & & & & Dec. & Mar. & \\
\hline Eccoptomera obscura & $2 \widehat{\jmath}$ & & $1 \delta 1 \%$ & & 19 & $x$ \\
\hline Eccoptomera pallescens & & & 3 우 & 1 우 & & WM \\
\hline Orbellia hiemalis & 2 우 & & & & & $\mathrm{x}$ \\
\hline Schroederella iners & 1 우 & & & & & $\mathrm{X}$ \\
\hline Tephrochlamys rufiventris & & & $10^{\pi}$ & & & WM \\
\hline
\end{tabular}

only (not subject to a time limit), were excluded from the environmental analysis and only used in the compilation of the list of species and analysis of seasonal dynamics. These traps were operated wherever there was snow cover.

In order to analyse the biocenotic structure of the catches, dominance (D), frequency (F) and Q index (geometric mean of frequency and dominance) were calculated. To explain the relationship between the ambient temperature and number of active Heleomyzidae, Pearson's correlation coefficients at a significance level $p<0.05$ were calculated. Variables such as the number of individuals and the maximum number of species were included in this calculation. The null hypothesis of no correlation between the activity of heleomyzids on snow and air temperature was tested. All the statistical calculations were done in Statistica 10.0 (StatSoft, 2011).

A checklist of winter active European Heleomyzidae was drawn up. The list was based on data from 71 papers (numbered in References) and the records reported in this study. It included all information about their occurrence on snow, in pitfall traps, yellow traps or just on their activity between November and March/April.

\section{RESULTS}

A total of 408 adult individuals were sampled, which belonged to 27 species and three subfamilies: Heleomyzinae, Heteromyzinae and Suilliinae. Heleomyzinae were eu- 


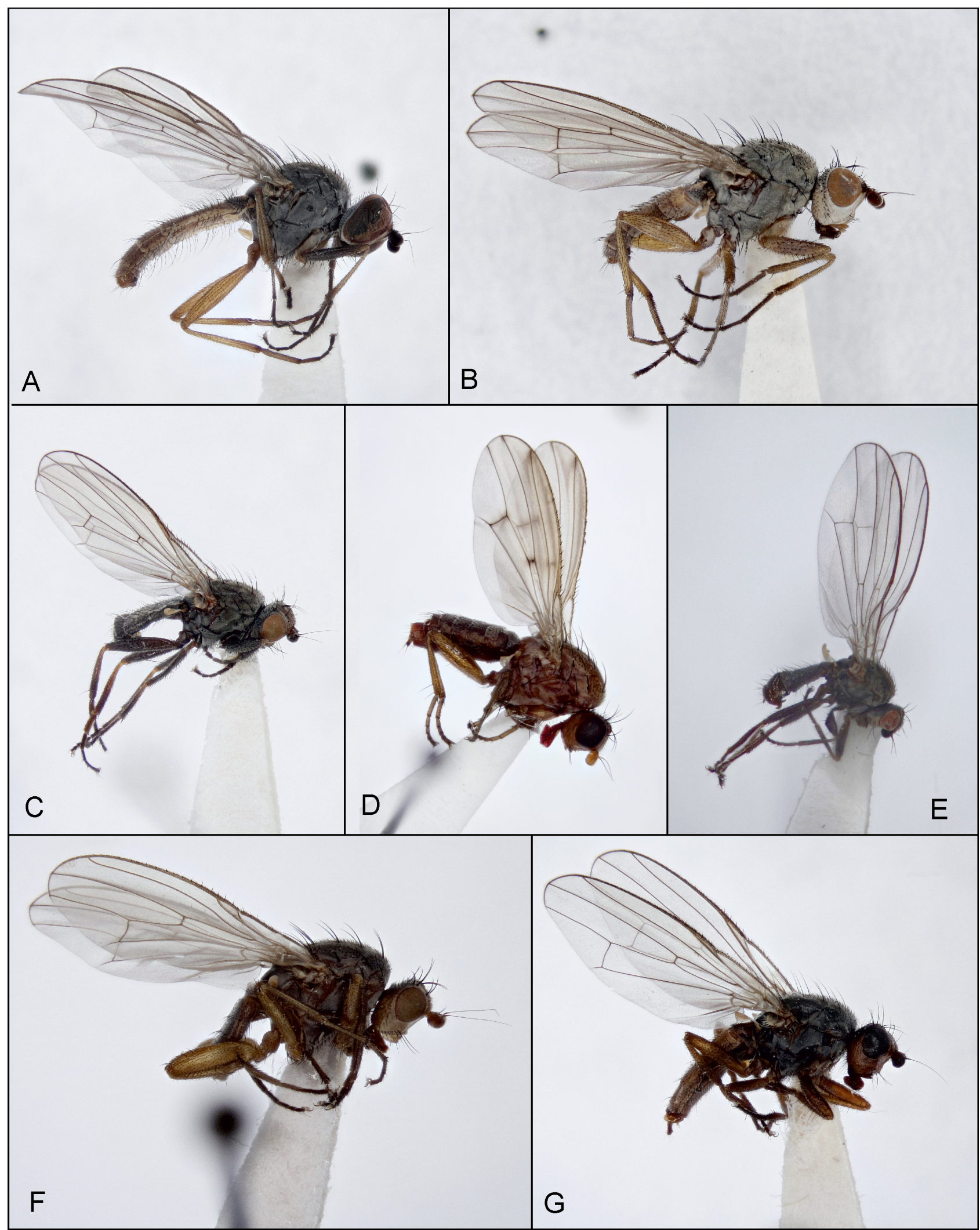

Fig. 3. Photographs of the characteristic species of Heleomyzidae recorded on snow. A - Heteromyza rotundicornis, male; B - Tephrochlamys rufiventris, male; C - Heleomyza modesta, male; D - Suillia parva, female; E - Oldenbergiella brumalis, male; $\mathrm{F}$ - Eccoptomera obscura, male; G - Scoliocentra (Leriola) brachypterna, female.

dominant in the material (17 species and 64\% of individuals). Detailed data on the species and the structure of the assemblage are listed in Table 2. More males (221 indiv.) than females (187 indiv.) were collected on snow.
Four of the species appeared almost equally dominant in the combined material from lowland and mountains, although they differed in frequency. Heleomyza modesta (Fig. 3C) was the most abundant and most frequent species 
among all the Heleomyzidae collected on snow. Heteromyza rotundicornis (Fig. 3A), Scoliocentra brachypterna (Fig. 3G) and Tephrochlamys rufiventris (Fig. 3B) were similarly abundant but less frequent. The $\mathrm{Q}$ index, a geometric mean of frequency and dominance, indicated these four species as the most characteristic for the assemblage investigated.

Lowland and mountain assemblages differed in species composition and community structure. Among the 18 species recorded in the lowlands $T$. rufiventris was predominant, followed by Eccoptomera obscura (Fig. 3F) and Heteromyza rotundicornis. Fourteen species were recorded in the Beskid Sądecki Mts community. Here, Heleomyza modesta and S. brachypterna predominated, followed by Heteromyza rotundicornis. Two more heleomyzids were caught in other montane areas: Suillia cepelaki and Morpholeria kerteszii. Among the five heleomyzids that were recorded in both lowland and mountain communities, only Heteromyza rotundicornis was almost equally represented in both regions. Two other species were abundant only in the lowlands (T. rufiventris and E. obscura) and one mainly in the mountains (Gymnomus caesius).

\section{Pitfall traps}

No heleomyzids were caught by the Moericke traps placed on snow during winter, neither in the lowlands nor the mountains. However, five species were recorded in pitfall traps in the lowlands (meadows at the edge of a forest) during a period when there was no snow present (Table 3 ).

\section{Seasonal variation}

The study of snow active flies was carried out whenever snow was present, from the second half of November to March (in the lowlands) and April (in the mountains). Separate samples for late October, early November and mid-April, were collected following abnormally early or late snowfalls.

In the lowlands, Heleomyzidae began to appear on snow in late November and continued to occur there until the end of December, but later on their number decreased. In the mountains the number of specimens collected increased from the second half of December and reached a peak at the beginning of February (Fig. 4). Table 4 shows the seasonal variation in catches on snow throughout winter. The Heleomyzidae differed in their seasonal activity. One group of species, which occurred in late autumn/early winter and disappeared in mid-December, consisted of Orbellia cuniculorum, Morpholeria kerteszii, Suillia vaginata, S. pallida, O. hiemalis and Tephrochlamys flavipes. However, the abundance of these species was so low that their occurrence then may be accidental. The other group consisted of winter species, which were active during almost the whole autumn/spring period, i.e. the dominant species and the less abundant Gymnomus caesius. Another group of species consisting of Orbellia myopiformis, Scoliocentra brachypterna, S. nigrinervis, G. spectabilis and Eccoptomera longiseta were mainly collected in mid-winter. A few species started or increased their activity in March

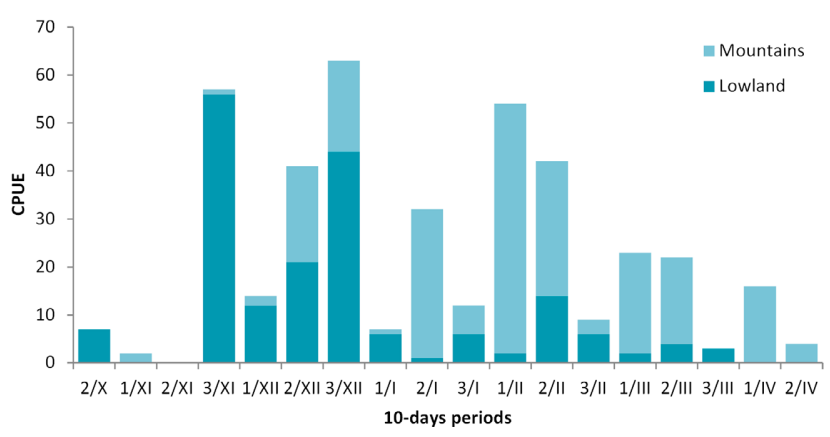

Fig. 4. Phenology of Heleomyzidae recorded on snow in Poland, (CPUE - catch per unit effort). Ten-day periods and months are as follows: e.g. 2/XII stands for mid-December. The slight differences in the colour of each of the columns indicate the catches recorded in the lowlands and mountains.

and April: Suillia parva (Fig. 3D), Heteromyza atricornis, Heleomyza captiosa and Scoliocentra villosa. This group includes a few individuals of accidentally occurring species.

\section{Influence of weather}

Heleomyzidae were found alive on the surface of snow at temperatures between $-5^{\circ} \mathrm{C}$ and $+8^{\circ} \mathrm{C}$ (Fig. 5) and at $53-100 \%$ air humidity. However, the largest number of individuals and species were collected between $-2.5^{\circ} \mathrm{C}$ and $+2{ }^{\circ} \mathrm{C}$ and at a high humidity $(80-100 \%)$ (Fig. 6). Three species of Heleomyzidae were recorded when the samples were collected at the lowest temperatures: Scoliocentra nigrinervis $\left(-5^{\circ} \mathrm{C}\right)$, Heleomyza modesta $\left(-4^{\circ} \mathrm{C}\right)$ and Orbellia myopiformis $\left(-4^{\circ} \mathrm{C}\right)$. All of the most important taxa in the assemblage studied were recorded between $-5^{\circ} \mathrm{C}$ and $+2^{\circ} \mathrm{C}$. Above $+2{ }^{\circ} \mathrm{C}$, mainly accidental and less abundant species were recorded (Table 5, Fig. 5).

All the Heleomyzidae collected on snow were alive. As air temperatures increased, there was always a greater tendency for the flies to fly away when disturbed. Flying heleomyzids were observed at air temperatures higher than about $2^{\circ} \mathrm{C}$. However, part of the population was still sitting in the characteristic "starting position" (Fig. 7C), very often on the higher sites on natural piles or banks of snow. Flying Heleomyzidae were not collected.

Regression analysis of the activity of heleomyzids over the range of air temperatures from $-5^{\circ} \mathrm{C}$ (the lowest recorded temperature) to c. $+2^{\circ} \mathrm{C}$, the temperature when flying heleomyzids were observed, (Fig. 8A) confirmed the positive effect of an increase in air temperature $\left(\mathrm{R}^{2}=0.7264\right.$; $\mathrm{P}$ $=0.0072)$ on the number of specimens recorded on snow, on maximum species richness $\left(\mathrm{R}^{2}=0.8578 ; \mathrm{P}=0.0010\right)$, on the number of males $\left(\mathrm{R}^{2}=0.7651 ; \mathrm{P}=0.0045\right)$ and females $\left(\mathrm{R}^{2}=0.6331 ; \mathrm{P}=0.0182\right)$, and on abundance in the lowlands $\left(\mathrm{R}^{2}=0.6133 ; \mathrm{P}=0.0215\right)$ and mountains $\left(\mathrm{R}^{2}=\right.$ $0.5698 ; \mathrm{P}=0.0304)$. The same positive statistical confirmation (Fig. 8B) was obtained for the relation between increasing air humidity and the number of Heleomyzidae specimens $\left(\mathrm{R}^{2}=0.8359 ; \mathrm{P}=0.0298\right)$ and species diversity $\left(\mathrm{R}^{2}=0.9055 ; \mathrm{P}=0.0344\right)$. 
Table 4. Heleomyzidae recorded on snow in Poland during this study. Ten-day periods and months are given; e.g., 2/XII stands for second decade of December.

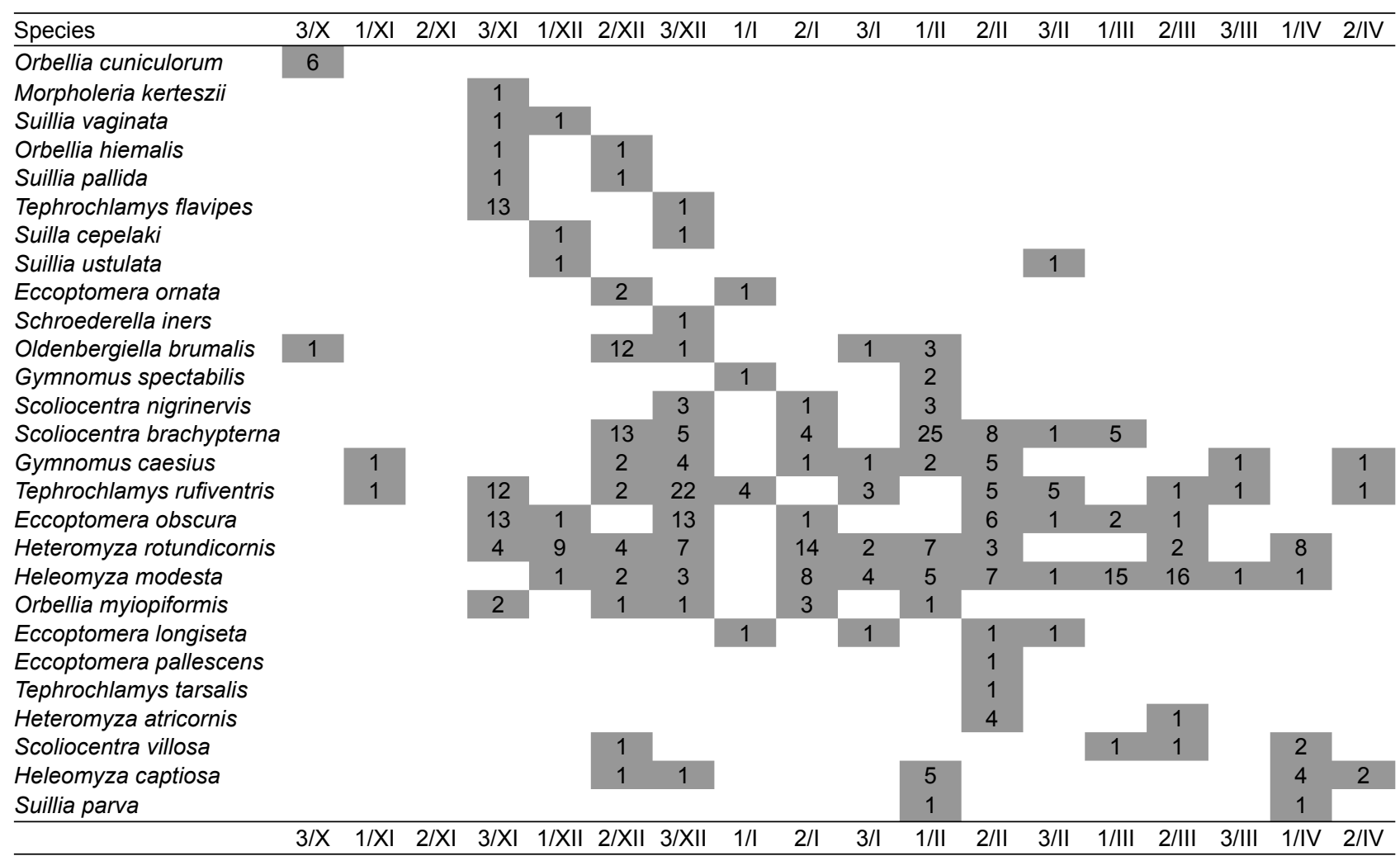

Taxonomic comments on the species list of winteractive Heleomyzid flies

\section{Gymnomus caesius (Meigen, 1830)}

Helomyza caesia Meigen, 1830: 56.

= Helomyza nivalis Wahlgren, 1918: 4, syn. n.

The junior author had the opportunity to study the holotype of Helomyza nivalis Wahlgren, 1918 during his stay in Lund in 2002. This revealed that $H$. nivalis is a junior synonym of Helomyza caesia Meigen, 1830, later transferred to the genus Gymnomus Loew by Papp \& Woźnica (1993). H. nivalis was considered a nomen dubium in the Catalogue of Palaearctic Diptera (Gorodkov, 1984).

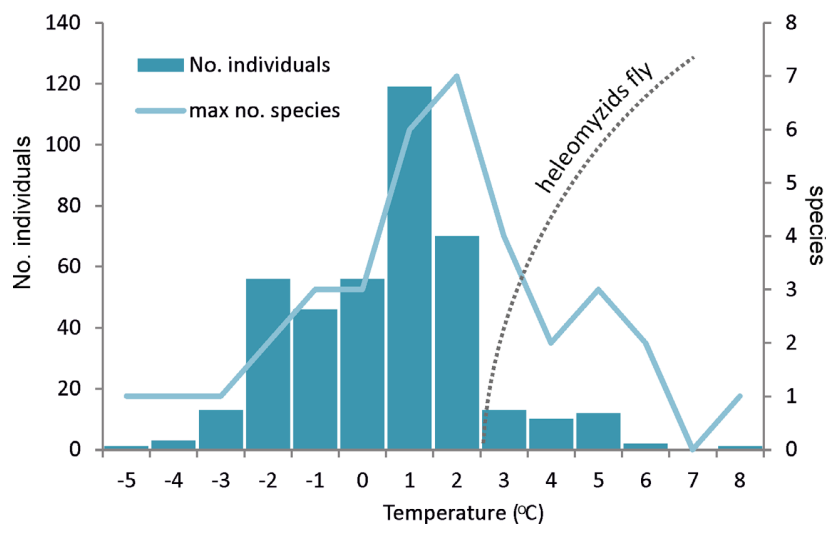

Fig. 5. Total numbers of individuals and species of Heleomyzidae recorded on snow at different air temperatures; curved dotted line indicates the temperature when Heleomyzidae were recorded flying.

\section{Supplementary description of Helomyza nivalis}

Body length: $4.5 \mathrm{~mm}$. Cheek-eye ratio: 0.5. Anterior orbital seta about 0.5 of the length of the second orbital bristle. Antenna: scape and pedicel brick-reddish in colour, first flagellomere brown distally. Arista longer than head width. Fourteen small hairs in anterior corner of anepisternum. Dorsocentral bristles on dark brown (brownishblack) spots. Wing medial vein ratio: 1.24. Head ratio: 1.1. Fore femora more greyish-brown distally. Four dorsal bristles on hind femur. Male terminalia typical of Gymnomus caesius (Meigen, 1830) as described by Papp \& Woźnica (1993). According to the femoral chaetotaxy and grey postpronotal area this species corresponds exactly to couplet 16(-) in Woźnica's (2011) key.

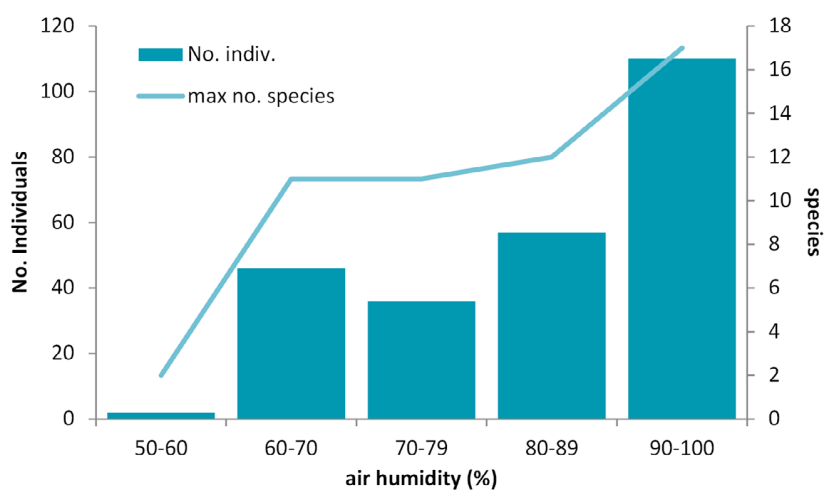

Fig. 6. The relationship between numbers of Heleomyzidae recorded on the snow and humidity. 
Table 5. Heleomyzidae recorded on snow in Poland: numbers of specimens and temperatures $\left({ }^{\circ} \mathrm{C}\right)$ at which they were recorded.

\begin{tabular}{|c|c|c|c|c|c|c|c|c|c|c|c|c|c|c|}
\hline Species & -5 & -4 & -3 & -2 & -1 & 0 & 1 & 2 & 3 & 4 & 5 & 6 & 7 & 8 \\
\hline Scoliocentra nigrinervis & 1 & & 1 & 2 & & & 2 & 1 & & & & & & \\
\hline Orbellia myiopiformis & & 1 & & 3 & 1 & & 3 & & & & & & & \\
\hline Heleomyza modesta & & 2 & 3 & 20 & 4 & 8 & 11 & 11 & 1 & 3 & 1 & & & \\
\hline Tephrochlamys rufiventris & & & 4 & 13 & 12 & 14 & 10 & 1 & & 1 & 1 & & & \\
\hline Heteromyza rotundicornis & & & 4 & 7 & 7 & 8 & 24 & 8 & & & & & & 1 \\
\hline Eccoptomera ornata & & & 1 & & & 2 & & & & & & & & \\
\hline Oldenbergiella brumalis & & & & 8 & 3 & 2 & 3 & & 1 & & & & & \\
\hline Scoliocentra brachypterna & & & & 1 & 3 & 4 & 30 & 21 & & 2 & & & & \\
\hline Suilla cepelaki & & & & 1 & & & 1 & & & & & & & \\
\hline Scoliocentra villosa & & & & 1 & & & 1 & 3 & & & & & & \\
\hline Tephrochlamys flavipes & & & & & 13 & 1 & & & & & & & & \\
\hline Orbellia hiemalis & & & & & 1 & 2 & 5 & 3 & & & & & & \\
\hline Suillia vaginata & & & & & 1 & & 1 & & & & & & & \\
\hline Suillia ustulata & & & & & 1 & & & & & & & 1 & & \\
\hline Schroederella iners & & & & & & 1 & & & & & & & & \\
\hline Gymnomus spectabilis & & & & & & 1 & & 1 & & & & & & \\
\hline Eccoptomera pallescens & & & & & & & 1 & & & & & & & \\
\hline Morpholeria kerteszii & & & & & & & 1 & & & & & & & \\
\hline Suillia parva & & & & & & & 1 & & & & & & & \\
\hline Orbellia cuniculorum & & & & & & & & & 6 & & & & & \\
\hline Heteromyza atricornis & & & & & & & 2 & 2 & & & & & & 1 \\
\hline Eccoptomera obscura & & & & & & 10 & 13 & 14 & & 1 & & & & \\
\hline Heleomyza captiosa & & & & & & 3 & 4 & 1 & & 1 & 4 & & & \\
\hline Gymnomus caesius & & & & & & & 7 & 5 & 1 & 2 & 2 & & & \\
\hline Suillia pallida & & & & & & & & 1 & & & 1 & & & \\
\hline Eccoptomera longiseta & & & & & & & & 1 & & & 1 & 1 & & \\
\hline Tephrochlamys tarsalis & & & & & & & & 1 & & & & & & \\
\hline & -5 & -4 & -3 & -2 & -1 & 0 & 1 & 2 & 3 & 4 & 5 & 6 & 7 & 8 \\
\hline
\end{tabular}

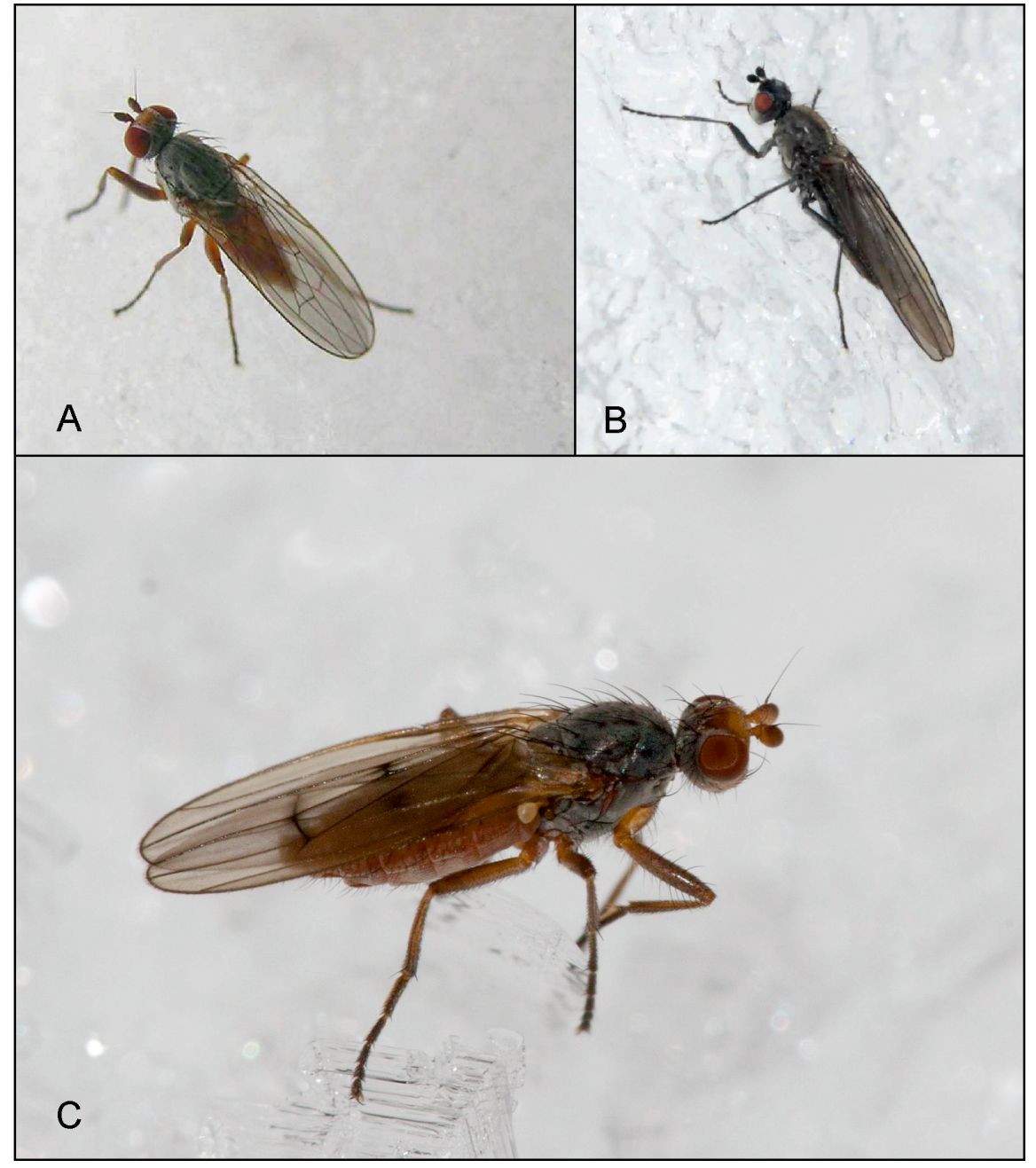

Fig. 7. Photographs of Heleomyzidae recorded on the surface of snow. A - Tephrochlamys rufiventris, male; B - Orbellia hiemalis, female (photo $Ł$. Mielczarek); C - Scoliocentra (Leriola) nigrinervis, female (photo C. OvidiuManci). 

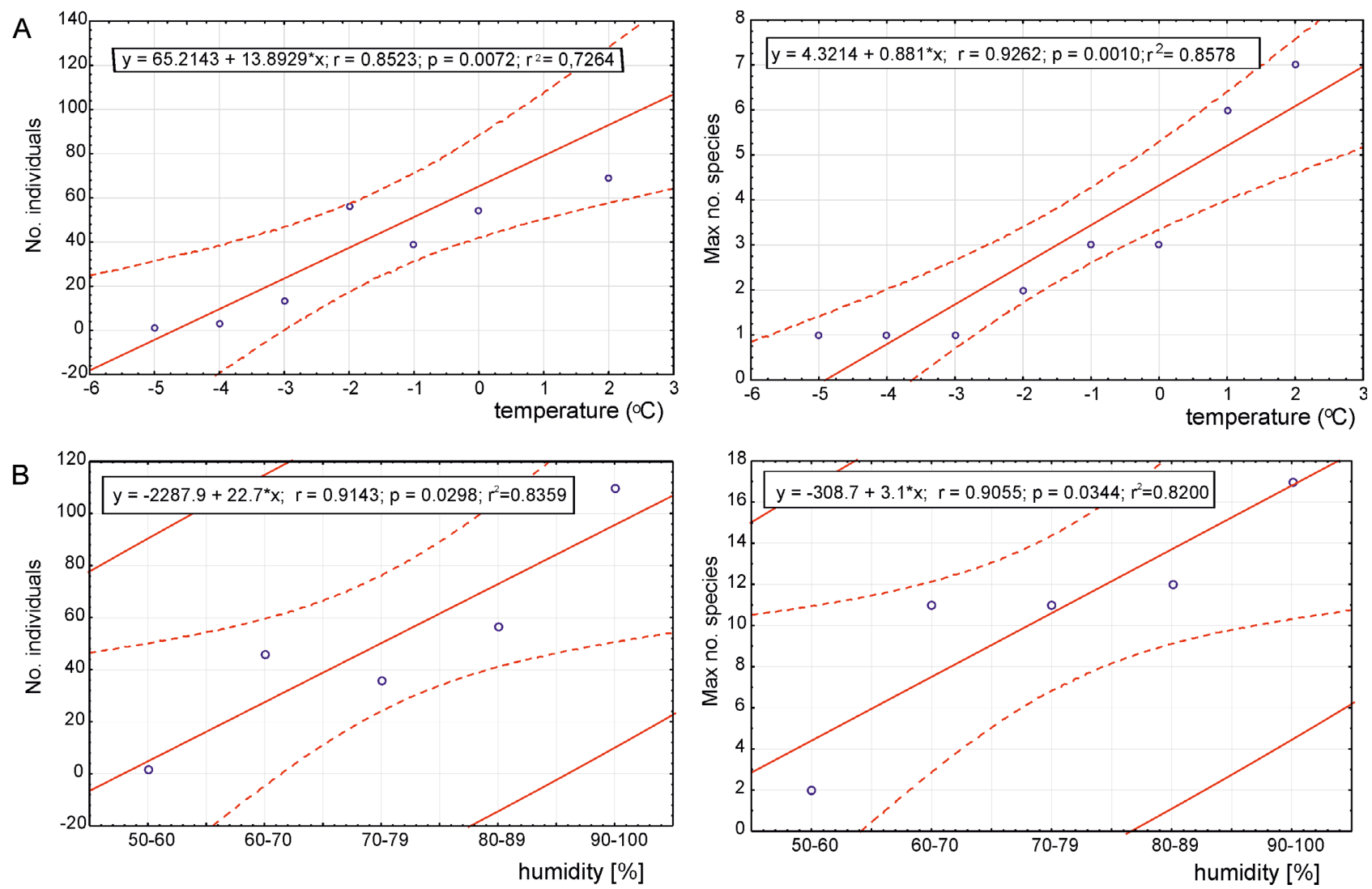

Fig. 8. Linear regression analysis showing the correlation between the number of individuals and species of Heleomyzidae recorded on snow and temperatures up to $2^{\circ} \mathrm{C}(\mathrm{A})$ and humidity $(\mathrm{B})$, at $\mathrm{p}<0.05$.

Material examined. Holotype $\widehat{\partial}$, labelled: Nkpy [= Nyköping] 31/12, Suö [white (yellowish due to age)]; Holotypus (red), Helomyza nivalis Wahlgr.; ZML 2001, 234 (green).

Remarks. Left hind tarsus missing. Specimen minutia pinned. Genitalia dissected and stored in a microvial of glycerine.

\section{Scoliocentra (Leriola) nigrinervis (Wahlgren, 1918)}

Helomyza nigrinervis Wahlgren, 1918: 3.

Scoliocentra bipunctata Müller, 1924 (1923): 88.

According to Gorodkov (1962a) this species is recorded under the name Leria maculipennis Becker, 1897 by Frey (1913), who did not include it in volume VI of Enumeratio Insectorum Fenniae (Frey, 1941). The last published Checklist of the Fly Families Chyromyidae and Heleomyzidae (Diptera) of Finland (Kahanpää, 2014) also does not include this species name, although it should be mentioned that Tahvonen (1942) cites Leria maculipennis from Jyväskylä, central Finland. The distribution of Sc. (Leriola) maculipennis, given in detail by Gorodkov (1962a), indicates that it is an Arctic species probably widely distributed in the Holarctic Region (Gorodkov, 1984). Tahvonen's data are included in the list under the name Scoliocentra nigrinervis.

\section{Suillia univittata (von Roser, 1840)}

Helomyza univittata von Roser, 1840: 61. Helomyza agaricina Rondani, 1867: 119.
Some specimens of Suillia univittata (von Roser, 1840) are placed in collections under the species name Suillia lurida (Meigen, 1830) (Martinek, 1972); however we follow the interpretation of Séguy (1934) and Martinek (1972) in regarding them as well separated species. Therefore, all published data where Suillia univittata is quoted as lurida (specified in Martinek, 1972) are included under univittata in the species list (see Table 6).

\section{DISCUSSION}

\section{Heleomyzidae - a cold adapted and winter active group}

Heleomyzids are known to prefer cold and extreme habitats, such as caves, cold mountains and snow-covered areas. Their most northerly locality is Spitsbergen $(\mathrm{Cz}-$ erny, 1924; Papp, 1981). The preference for a cool climate may have been a characteristic of the Heleomyzidae from early in their evolution, which began in the Cenozoic in northern Europe (Gorodkov, 1972). The current distribution of western Palearctic heleomyzids indicates that the recent European fauna developed in a mountainous area south of the Polar Circle and survived the glaciation in numerous isolated refuges in mountains in Western and Central Europe. It concerns mostly species now classified within the subfamily Heleomyzinae and belonging to the genus Gymnomus (Woźnica, 1996). With all probability the Heleomyzid fauna dispersed from south to north during the interglacial periods (Gorodkov, 1972). This may explain the disjunctive distribution of some snow-active 
Heleomyzidae, such as Heleomyza modesta, Scoliocentra brachypterna, Suillia parva and Scoliocentra nigrinervis. The last mentioned species is very common in Scandinavia (Hågvar \& Greve, 2003), while in the rest of Europe it occurs only in the Western Carpatians, above $700 \mathrm{~m}$ a.s.1. (Soszyńska \& Woźnica, 2012). Apparently, Scoliocentra nigrinervis did not colonize lowland regions when the glaciers retreated but remained in the cooler mountainous habitats.

As many as 27 species of heleomyzids were recorded on snow in Poland. Dominant species were Heleomyza modesta, Heteromyza rotundicornis, T. rufiventris, Scoliocentra brachypterna and to a lesser extent E. obscura. Ten of the 14 Heleomyzidae species recorded on snow in southern Norway (Hågvar \& Greve, 2003; Frey, 1913) were also recorded in Poland with the same dominant taxon - Scoliocentra brachypterna. In Germany, Bährmann \& Adaschkiewitz (2003) stated that some taxa are typically winter-active: Heleomyza modesta, G. caesius, E. obscura, Suillia oxyphora, S. pallida, S. vaginata, Schroederella iners and Tephrochlamys laeta. In Poland, several species of this cold-adapted family were recorded only in mountains (Table 2). Species of the genera Gymnomus, Heleomyza, Scoliocentra, and Suillia cepelaki are most abundant in natural forests in the mountains. These flies naturally occur in wooded areas (Woźnica, 1996). In contrast, species of the genera Eccoptomera, Oldenbergiella and Orbellia occur mainly in less forested areas, and dominate in the lowlands.

Additional results from our winter study are the new faunistic records of Heleomyzidae in Poland. One species of Heleomyzidae is new to the Polish fauna - Suillia cepelaki (Woźnica \& Soszyńska-Maj, in press), one was previously known only from a single Polish record - Scoliocentra nigrinervis (Soszyńska-Maj \& Woźnica, 2012). The record of Suillia cepelaki in Polish mountains is the most northern known occurrence of this species in Europe, and probably also the northernmost border of its distribution (Woźnica \& Soszyńska-Maj, in press). Among the lowland species, records of E. ornata are especially noteworthy. This species was recorded in this study for the first time both on the snow and in the lowlands. Previously, it was recorded in Poland exclusively in the mountains (Woźnica, 2007). These results demonstrate the importance of winter studies when updating lists of some groups of insects, particularly those that are mainly active in cold weather. This was previously demonstrated for winter emerging Chironomidae (Soszyńska-Maj et al., 2016).

On the basis of the new data from Poland and literature on winter-active flies and Heleomyzidae recorded on snow, a list of 78 winter-active Heleomyzidae in Europe was compiled (Table 6) (papers are numbered in References and cited in Table 6 by those numbers). One species recorded on snow in Poland had never previously been noted for its winter activity. Every species in the list of 78 winter-active taxa could be potentially recorded on snow. Winter-active Heleomyzidae make up almost $52 \%$ of the whole family, making these flies the most winter active group of Diptera other than the Trichoceridae (SoszyńskaMaj et al., in prep.).

The absence of Heleomyzidae in pitfall traps under snow leads to the conclusion that these flies do not seek protection from the weather in the subnivean space beneath the snow as other insects do (Koshima, 1984, 1985). This is undoubtedly due to their wings, which are significantly longer than the abdomen and would make boring into deep snow cover impossible.

\section{Phenology}

Records of Heleomyzidae on snow in the lowlands were highest in late November and December. In the mountains, however, they appeared at the end of December and peaked at the beginning of February. These differences are mainly determined by the dominant species. All the dominant species in the lowlands were recorded on snow throughout the autumn-spring period (T. rufiventris, E. obscura, Heteromyza rotundicornis), but were more abundant in late autumn and early winter. However, the activity on snow of the two most abundant species in the mountains (Heleomyza modesta and Scoliocentra brachypterna) peaked in mid-winter, i.e. January and February. Hågvar \& Greve (2003) also report Scoliocentra brachypterna and T. rufiventris occurring on snow in Norway at this time. In Germany, Bährmann \& Adaschkiewitz (2003) reports collecting 27 species of Heleomyzidae in winter and provides details of the winter phenology of 10 species. The phenology they cite for Heleomyza modesta corresponds with our data.

\section{Response to weather conditions}

The group of species recorded at the lowest temperatures included those that occur only in the mountains (Scoliocentra nigrinervis, $-5^{\circ} \mathrm{C}$ and Heleomyza modesta, $-4^{\circ} \mathrm{C}$ ) and those that were present both in mountain and lowland assemblages (O. myiopiformis, E. ornata, T. rufiventris). A single species, Heteromyza rotundicornis, common in both assemblages, had the widest temperature range. Species that were recorded in the lowlands predominated at the highest winter temperatures.

Highest number of individuals and species of Heleomyzidae were collected between $-2^{\circ} \mathrm{C}$ and $2^{\circ} \mathrm{C}$ and at from 91 to $100 \%$ humidity. The positive effect of rising air temperature and humidity were statistically confirmed. Very often, heleomyzids were collected when the weather was cloudy or even foggy, which indicates stable weather without rapid temperature changes. At air temperatures lower than $-3.5^{\circ} \mathrm{C}$, heleomyzids were only recorded on the snow occasionally, while above $2^{\circ} \mathrm{C}$ they were commonly seen flying. The lowest temperature at which they are recorded is reported by Svensson (1966), who found Scoliocentra nigrinervis at $-8^{\circ} \mathrm{C}$, and this species can survive down to $-16^{\circ} \mathrm{C}$ in a supercoooled state (Sømme \& Østbye, 1969). Our study in Poland confirmed that this species was active at the lowest temperature recorded $\left(-5^{\circ} \mathrm{C}\right)$. The majority of other field observations of these insects on snow were made at temperatures between -2 and $+2{ }^{\circ} \mathrm{C}$ (Frey, 1913; Tahvonen, 1942; Hågvar \& Greve, 2003). However, Sco- 
Table 6. A checklist of European Heleomyzidae, including species recorded in winter, based on this study and records in the literature. Sources are numbered in References. * - this paper, $\mathrm{S}$ - recorded on snow but no record of the month collected, W- recorded in winter but without a specific date.

\begin{tabular}{|c|c|c|c|c|c|}
\hline No. & Species & Snow cover & Pitfall traps & Winter activity & Source \\
\hline 1 & Acantholeria vockerothi Hackman, 1969 & & & $\mathrm{XII-II}$ & (19) \\
\hline 2 & Eccoptomera emarginata Loew, 1862 & $\mathrm{~S}$ & & $\mathrm{XI}-\mathrm{XII}$ & (67) \\
\hline 3 & Eccoptomera longiseta (Meigen, 1830) & II & $\mathrm{X}-\mathrm{III}$ & I-II & $*(09,35,49,59)$, \\
\hline 4 & Eccoptomera microps (Meigen, 1830) & XII & & $\mathrm{X}-\mathrm{II}$ & $(19,35,44,58,63,67)$ \\
\hline 5 & Eccoptomera obscura (Meigen, 1830) & $\mathrm{XI}-\mathrm{III}$ & XI-XII,III,W & X-XII,IV, W & * $(01,02,19,27,48,66)$ \\
\hline 6 & Eccoptomera ornata Loew, 1862 & XII-I & & & * \\
\hline 7 & Eccoptomera pallescens (Meigen, 1830) & $\mathrm{XI}, \mathrm{II}$ & $\mathrm{X}, \mathrm{XII}, \mathrm{W}$ & $\mathrm{X}-\mathrm{IV}$ & * $(01,02,20,35,36)$ \\
\hline 8 & Gymnomus amplicornis (Czerny, 1924) & & & II-III,W & $(02,12,63)$ \\
\hline 9 & Gymnomus caesius (Meigen, 1830) & $\mathrm{XI}-\mathrm{II}$ & W & $\mathrm{XII}-\mathrm{II}, \mathrm{W}$ & ${ }^{*}(01,02,19,24,28,36,39,40,54,68)$ \\
\hline 10 & Gymnomus ceianui (Martinek, 1985) & & & $X, X I I-I I$ & $(07,15,52,54)$ \\
\hline 11 & Gymnomus martineki Papp \& Woźnica, 1993 & & & II & $(19)$ \\
\hline 12 & Gymnomus sabroskyi (Gill, 1962) & & IV & W & (45) \\
\hline 13 & Gymnomus spectabilis (Loew, 1862) & $\mathrm{I}-\mathrm{II}, \mathrm{W}$ & & XII & ${ }^{*}(01,06)$ \\
\hline 14 & Heleomyza borealis (Boheman, 1865) & III-IV & V & II-IV & $(05,36,60)$ \\
\hline 15 & Heleomyza captiosa (Gorodkov, 1962) & II,IV & W & $\mathrm{X}-\mathrm{IV}$ & * $(01,02,09,12,19,20)$ \\
\hline 16 & Heleomyza modesta (Meigen, 1835) & XII-IV & I-II & $\mathrm{X}-\mathrm{IV}$ & ${ }^{*}(01,02,07,12,15,19,24,28,32,39,57,63,66)$ \\
\hline 17 & Heleomyza serrata (Linnaeus, 1758) & XI,II-IV & W & XII-III,W & $(01,02,12,33,36,39,41,60)$ \\
\hline 18 & Heteromyza atricornis Meigen, 1830 & III & & $\mathrm{X}-\mathrm{III}, \mathrm{W}$ & ${ }^{*}(02,07,09,16,19,38)$ \\
\hline 19 & Heteromyza commixta Collin, 1901 & IV & & & $(36)$ \\
\hline 20 & Heteromyza oculata Fallen, 1820 & XII & & $\mathrm{XI}-\mathrm{XII}$ & $(36,19)$ \\
\hline 21 & Heteromyza rotundicornis (Zetterstedt, 1846) & $\mathrm{XI}-\mathrm{IV}$ & & $\mathrm{XI}-\mathrm{III}$ & * $(10,21,29,48)$ \\
\hline 22 & Morpholeria kerteszii Czerny, 1924 & $\mathrm{XI}$ & & & * \\
\hline 23 & Morpholeria ruficornis (Meigen, 1830) & & $\mathrm{X}$ & $\mathrm{XI}, \mathrm{XII}, \mathrm{W}$ & $(02,04,08,19,28)$ \\
\hline 24 & Neoleria flavicornis (Loew, 1862) & & & I-III & $(09,20)$ \\
\hline 25 & Neoleria maritima (Villeneuve, 1921) & & & $\mathrm{XI}-\mathrm{XII}, \mathrm{II}$ & $(06,09)$ \\
\hline 26 & Neoleria propinqua Collin, 1943 & & & XII & $(41)$ \\
\hline 27 & Neoleria ruficauda (Zetterstedt, 1847) & & & $X I-I-I I I$ & $(06,12,20)$ \\
\hline 28 & Neoleria ruficeps (Zetterstedt, 1838) & & & XI-XII & $(06,15,41,66)$ \\
\hline 29 & Oecothea fenestralis (Fallen, 1820) & XII & W & $\mathrm{X}-\mathrm{IV}$ & $(01,02,09,40,55,59)$ \\
\hline 30 & Oecothea ushinskii Gorodkov, 1959 & & & XII & $(15)$ \\
\hline 31 & Oldenbergiella blascoi Carles-Tolrá, 1995 & & & $\mathrm{XII}, \mathrm{II}$ & $(15,19)$ \\
\hline 32 & Oldenbergiella brumalis Czerny, 1924 & $\mathrm{X}-\mathrm{II}$ & & $\mathrm{X}-\mathrm{XI}$ & *(57,69) \\
\hline 33 & Oldenbergiella calcacifera Papp, 1980 & & & $\mathrm{X}-\mathrm{III}$ & $(12,20,47,48,51,57)$ \\
\hline 34 & Oldenbergiella canalicata Carles-Tolrá, 1998 & & & $\mathrm{I}, \mathrm{III}$ & $(12,20)$ \\
\hline 35 & Oldenbergiella pappi Carles-Tolrá, 1992 & & & $\mathrm{XII}, \mathrm{II}$ & $(09,15)$ \\
\hline 36 & Oldenbergiella seticerca Papp,1980 & & & X-XII,II-III & $(12,20,47,55,66)$ \\
\hline 37 & Orbellia borisregis Czerny, 1930 & II & & II & $(25)$ \\
\hline 38 & Orbellia cuniculorum Robineau-Desvoidy, 1830 & $\mathrm{X}$ & & XII,III & *(12,56) \\
\hline 39 & Orbellia hiemalis (Loew, 1862) & $\mathrm{X}-\mathrm{XII}$ & $\mathrm{XI}$ & $\mathrm{XI}-\mathrm{II}$ & * $(24,39,48,55,66,71)$ \\
\hline 40 & Orbellia myiopiformis Robineau-Desvoidy, 1830 & $\mathrm{XI}-\mathrm{II}$ & & $\mathrm{XI}-\mathrm{IV}$ & * $(12,20,24,36,48,55,59,63,69)$ \\
\hline 41 & Orbellia nivicola (Frey, 1913) & $\mathrm{XI}-\mathrm{I}$ & & & $(30,36,55,64)$ \\
\hline 42 & Schroederella bifida Papp \& Carles-Tolrá, 1994 & & & $\mathrm{XI}-\mathrm{XII}$ & $(15)$ \\
\hline 43 & Schroederella iners (Meigen, 1830) & XI-XII & $\mathrm{X}-\mathrm{XI}, \mathrm{W}$ & $\mathrm{X}-\mathrm{III}$ & * $(01,02,23,50,53,66,69)$ \\
\hline 44 & Schroederella hispanica Papp \& Carles-Tolrá, 1994 & & & XII-III & (15) \\
\hline 45 & Schroederella hungarica Papp \& Carles-Tolrá, 1994 & & & I & (66) \\
\hline 46 & Scoliocentra (Leriola) brachypterna (Loew, 1873) & I-IV & & $X, I I-I I I$ & *(02,36) \\
\hline 47 & Scoliocentra (Leriola) nigrinervis (Wahlgren, 1918) & $\mathrm{XI}-\mathrm{IV}$ & & $\mathrm{I}-\mathrm{III}^{*}, \mathrm{~W}$ & ${ }^{*}(01,25,30,31,36,43,56,62,63,65)$ \\
\hline 48 & Scoliocentra (Scoliocentra) dupliciseta (Strobl, 1898) & & & I & $(46,59,69)$ \\
\hline 49 & Scoliocentra (Scoliocentra) villosa (Meigen, 1830) & II-IV & & W & $*(02,61)$ \\
\hline 50 & Suillia affinis (Meigen, 1830) & & $\mathrm{X}, \mathrm{W}$ & $\mathrm{X}-\mathrm{XII}, \mathrm{IV}$ & $(01,02,04,11,28)$ \\
\hline 51 & Suillia atricornis (Meigen, 1830) & & & $\mathrm{X}-\mathrm{XI}, \mathrm{II}$ & (19) \\
\hline 52 & Suillia bicolor (Zetterstedt, 1838) & & & W & (02) \\
\hline 53 & Suillia cepelaki Martinek, 1985 & XII & & $?-\mathrm{IV}$ & ${ }^{*}(56)$ \\
\hline 54 & Suillia discolor Czerny, 1927 & & & XII & (11) \\
\hline 55 & Suillia gigantea (Meigen, 1830) & & W & 1 & $(01,15)$ \\
\hline 56 & Suillia flagripes (Czerny, 1904) & & & $\mathrm{XI}-\mathrm{I}$ & $(17,41)$ \\
\hline 57 & Suillia flava (Meigen, 1830) & & W & W & $(01,02)$ \\
\hline 58 & Suillia flavifrons (Zetterstedt, 1838) & $\mathrm{X}-\mathrm{II}, \mathrm{IV}$ & & W & $(02,30,36,55,67)$ \\
\hline 59 & Suillia fuscicornis (Zetterstedt, 1847) & & $X-X I, I I, W$ & $\mathrm{X}-\mathrm{II}, \mathrm{W}$ & $(01,02,04,17,28,41,60)$ \\
\hline 60 & Suillia humilis (Meigen, 1830) & & $\mathrm{X}-\mathrm{XI}, \mathrm{W}$ & $\mathrm{X}-\mathrm{III}, \mathrm{W}$ & $(01,02,04,07,08,12,15,19,28,34,35)$ \\
\hline 61 & Suillia laevifrons (Loew, 1862) & & $\mathrm{X}-\mathrm{XI}, \mathrm{W}$ & $X, W$ & $(01,02,04,28)$ \\
\hline 62 & Suillia notata (Meigen, 1830) & & W & $\mathrm{X}-\mathrm{II}$ & $(01,04,08,09,11,17,41)$ \\
\hline 63 & Suillia oxyphora (Mik, 1900) & & W & $x-1$ & $(01,02)$ \\
\hline 64 & Suillia pallida (Fallen, 1820) & $\mathrm{XI}-\mathrm{XII}$ & $\mathrm{X}, \mathrm{W}$ & $X-I V$ & ${ }^{*}(01,02,19,28,36,48,70)$ \\
\hline 65 & Suillia parva (Loew, 1862) & $I-I I$ & & XII,II-III & $*(12,36,63)$ \\
\hline 66 & Suillia setitarsis (Czerny,1904) & & & II-III & (26) \\
\hline 67 & Suillia similis (Meigen, 1838) & & W & W & $(01,02)$ \\
\hline 68 & Suillia tuberiperda (Rondani,1867) & I & & $|-| I \mid$ & $(37)$ \\
\hline 69 & Suillia ustulata (Meigen, 1830) & $\mathrm{XII}, \mathrm{II}$ & & III & *(48) \\
\hline 70 & Suillia umbratica (Meigen, 1835) & & & W & $(01,28)$ \\
\hline 71 & Suillia univittata (von Roser, 1840) [= lurida auct.] & & & $1-X$ & $(22,24,59)$ \\
\hline 72 & Suillia variegata (Loew, 1862) & & & XII-II & $(09,11,18,19,41)$ \\
\hline 73 & Suillia vaginata (Loew, 1862) & $\mathrm{XI}-\mathrm{XII}$ & W & $\mathrm{XI}-\mathrm{XII}$ & *(01,02) \\
\hline 74 & Tephrochlaena oraria (Collin, 1943) & & & I & $(16)$ \\
\hline 75 & Tephrochlamys flavipes (Zetterstedt, 1838) & $X \mathrm{I}-\mathrm{I}$ & $\mathrm{X}$ & XII-III,W & *$(02,09,11,12,14,16,19,20,29,34,40,41,48,55)$ \\
\hline 76 & Tephrochlamys laeta (Meigen, 1830) & $\mathrm{XI}-\mathrm{XII}$ & W & W & $(01,02,67)$ \\
\hline 77 & Tephrochlamys rufiventris (Meigen, 1830) & $\mathrm{XI}-\mathrm{IV}$ & $\mathrm{XI}-\mathrm{XII}, \mathrm{II}$ & $\mathrm{X}-\mathrm{IV}$ & $\begin{array}{c}*(01,02,04,06,09,11,19,24,26,29, \\
30,36,39,40,48,55,59,60,63,67)\end{array}$ \\
\hline 78 & Tephrochlamys tarsalis (Zetterstedt, 1847) & II & & $\mathrm{X}-\mathrm{XII}, \mathrm{II}-\mathrm{IV}$ & ${ }^{*}(48,60,67)$ \\
\hline
\end{tabular}


liocentra brachypterna, Heleomyza borealis, H. serrata and Heteromyza commixta were also recorded at higher temperatures (up to 5 or even $10^{\circ} \mathrm{C}$ ) on snow in southern Finland (Hågvar \& Greve, 2003).

\section{Ecology}

For some specialized arthropods, snow cover is an important refuge from extreme weather, e.g. wingless females of Geometridae (Soszyńska-Maj \& Buszko, 2011) and rich communities of Chironomidae (Soszyńska-Maj et al., 2016) and Triphleba trinervis (Phoridae) (Soszyńska \& Durska, 2002). The genera Boreus (Mecoptera) (Hågvar, 2001) and Chionea (Limoniidae) (Hågvar, 1971, 1976) also use snow surface as a refuge, as do many Collembola (review by Hågvar, 2010). The snow surface is also a stage for sexual behaviour and copulation for some taxa, such as, species of wingless and fully-winged Chironomidae (Jonsson \& Sandlung, 1975; Bouchard \& Ferrington, 2009; Giłka et al., 2013; Soszyńska-Maj et al., 2015).

During our study, we did not observe heleomyzids either copulating or walking on snow as is reported for winged Chironomidae (copulating and moving), Phoridae (walking) and Sphaeroceridae (walking) (Soszyńska \& Durska, 2002, Soszyńska-Maj, unpubl. data, Soszyńska-Maj et al., 2016). Only Svensson (1966) reports Scoliocentra nigrinervis moving on snow at a rate of $8-10 \mathrm{~cm}$ per minute. All Heleomyzidae collected in Poland were standing on the snow motionless, unless they were disturbed. Hågvar \& Greve (2003) also note that Heleomyzidae recorded on snow do not use the snow surface for walking, migration, copulation or sexual behaviour (only one such record), or for feeding or basking.

All available data on the biology of Heleomyzidae indicates their larvae are either saprophagous or mycetophagous, and this influences the phenology and habitat preferences of the adult. The adults of mycetophagous species of the genus Suillia occur in forests and in cool and shady places during autumn, which is confirmed by our results (Table 5). Autumnal and winter species whose larvae are necrophagous feed on carrion and prefer grassy and steppe areas (viz. Neoleria spp., Oldenbergiella spp., Orbellia spp. and Schroederella spp.). Larvae of the genera Heleomyza and Scoliocentra, some species of Heteromyza and Tephrochlamys rufiventris are probably saprophagous. Their adults appear in early spring and as the temperature rises they find shelter in caves and diapause there in summer. Locally, they stay permanently in caves as troglophiles. Heleomyza serrata, H. borealis, Scoliocentra brachypterna and $S$. villosa are mostly regarded as troglophiles and Heleomyza modesta and Eccoptomera pallescens as trogloxenes and are often recorded in caves in Norway, Austria and Poland (Østbye et al., 1987; Kjaerandsen, 1993; Christian \& Spötl, 2010; Østbye \& Lauritzen, 2013; Weber \& Weber, 2013). Populations of some heleomyzids also occur in burrows and soil tunnels made by small rodents or rabbits, in birds' nests, on guano in caves or even in old-fashioned toilets where they reproduce. Their saprophagous larvae develop in excrement, e.g. the larvae of Eccoptomera spp. in droppings of winter active rodents
(Czerny, 1924; Papp, 1981; Woźnica, 2008; Carles-Tolrá, 2011). The habitats that winter active Heleomyzidae prefer make them possible prey for shrews, which are active beneath the snow. Shrews feed on winter-active species rather than hibernating invertebrates (Ackefors, 1964; Randolph, 1973; Pernetta, 1977; Aitchison, 1984; Itämies \& Lindgren, 1989). Heleomyzidae may also be a source of food for bats in caves, as the winter diet of bats consists mainly of winter-active Diptera (Kaňuch et al., 2005; Williams et al., 2011).

During this study in Poland, slightly more males than females were collected on snow (male-to-female sex ratio is 1.2), which indicates that both sexes overwinter and copulate either in winter or not until spring. It should also be mentioned that some freshly emerged specimens with a balloon on the front of their heads were seen on the snow Scoliocentra nigrinervis (end of December) and Scoliocentra brachypterna (beginning of March). The latest studies on Diptera collected on carcasses in winter (Carles-Tolrá, 2011; Carles-Tolrá \& Prado e Castro, 2011) show that there are several species of Heleomyzidae that lay eggs in winter, and can be classified as cadaver colonizers [viz. $O$. brumalis Czerny (Fig. 3E)] with imagines common in late autumn and winter (Carles-Tolrá, 2011; Carles-Tolrá et al., 2011; Roháček, 1997).

Hågvar \& Greve (2003) point to the fact that during winter, the snow cover accumulates excrements and carrion like a big freezer, which is released when the snow melts. They hypothesized that cold-tolerant Heleomyzidae could be the first to colonize these resources at snow melt. In this way they could outcompete more heat demanding saprophagous insects which exploit the same food source, for example beetles and other Diptera. In support of this hypothesis, Hågvar \& Greve (2003) show that females of Scoliocentra nigrinervis contain mature eggs throughout winter, which they lay as soon as a favourable substrate becomes available. The occurrence on snow might reflect their continuous search for possible substrates, even at low temperatures. The overwintering of males furthermore indicates copulation when the substrate is available. We support this hypothesis. Also, some species may be able to find substrates for egg-laying in burrows or in caves, and stay active throughout the whole winter. However, we have not dissected females of Heleomyzidae to determine the number of egg they contain or the status of their ovaries.

Much is still left to learn about the ecology of this interesting, cold-tolerant family of flies. It would be interesting to determine whether carrion or dung placed in typical Heleomyzidae habitats during late winter is first colonized by these species and whether they are winners in utilizing resources exposed when snow melts.

ACKNOWLEDGEMENTS. We thank M. Łuszczak, B. Soszyński, A. Drozd, Ł. Mielczarek and A. Klasa (Poland) for supplying the insect material/records and C. Ovidiu-Manci (Romania) and $\iota$. Mielczarek (Poland) for the photographs of Scoliocentra nigrinervis and Orbellia hiemalis, respectively. We are grateful to E. Krzemińska (Poland) for help with the English version and anonymous reviewers for valuable remarks that significantly im- 
proved the manuscript. Special thanks go to R. Danielsson (curator emeritus of the Entomological Collections at Lund University, Sweden) for making available the holotype of Helomyza nivalis Wahlgren, 1918 for our studies.

\section{REFERENCES}

ACKEFors H. 1964: Winteractive shrews in the subnivean environment. - Zool. Revy 26: 16-22.

Aitchison C.W. 1974: A sampling technique for active subnivean invertebrates in southern Manitoba. - Manit. Entomol. 8: $32-36$.

Aitchison C.W. 1984: A possible subnivean food chain. In Merritt J.F. (ed.): Winter Ecology of Small Mammals. Carnegie Museum of Natural History, Pittsburgh, pp. 362-372.

Aitchison C.W. 2001: The effect of snow cover on small animals In Jones H.G., Pomeroy J., Walker D.A. \& Hoham R. (eds): Snow Ecology. Cambridge University Press, Cambridge, pp. 229-265.

Anderson A.M., Kranzfelder P., Bouchard R.W. \& Ferrington L. 2013: Survivorship and longevity of Diamesa mendotae Muttkowski (Diptera: Chironomidae) under snow. - J. Entomol. Acarol. Res. 45: 22-26.

'BäHRMANN R. 1996: Winteraktive Zweiflügler (Insecta, Diptera, Brachycera) in Xerothermrasen Thüringens. - Stud. Dipterol. 3: 259-274.

${ }^{2}$ Bährmann R. \& Adaschkiewitz W. 2003: Betrag zur Ökologie und Fauna der Heleomyzidae Mitteldeutschlands (Insecta: Diptera). - Faun. Abhandl. 24: 185-204.

${ }^{3}$ Beshovski V. \& Gueorgieva R.G. 2001: Review of the Bulgarian Heleomyzidae species (Insecta: Diptera). — Acta Zool. Bulgar. 53: 29-38.

${ }^{5}$ BJARNI E. \& GUdLEIFSSON B.E. 2002: List of invertebrates collected in pitfall traps in hayfields and pastures in NorthernIceland 1996-1997. - Icel. Agric. Sci. 15: 27-36.

BLOCK W. 2002: Interactions of water, ice nucleators and desiccation in invertebrate cold survival. - Eur. J. Entomol. 99: 259-266.

Bouchard R.W. JR. \& Ferrington L.C. JR. 2009: Winter growth, development, and emergence of Diamesa mendotae Muttkowski (Diptera: Chironomidae) in Minnesota (USA) streams. - Envir. Entomol. 38: 250-259.

Bouchard R.W. JR., Carrillo M.A., Kells S.A. \& Ferrington L.C. JR. 2006: Freeze tolerance in larvae of the winter-active Diamesa mendotae Muttkowski (Diptera: Chironomidae): a contrast to adult strategy for survival at low temperatures. Hydrobiologia 568: 403-416.

Bouchard R.W. JR., Schuetz B.E., Ferrington L.C. JR. \& Kells S.A. 2009: Cold hardiness in the adults of two winter stonefly species: Allocapnia granulata (Claassen) and A. pygmaea (Burmeister) (Plecoptera: Capniidae). - Aquat. Insects 31: $145-155$.

${ }^{4}$ Broen B. \& Mohrig W. 1965: Zur Frage der Winteraktivität von Dipteren in der Bodenstreu. - Dt. Entomol. Z. 12: 303-310.

${ }^{6}$ CARLes-Tolrá M. 1992: New and interesting records of Diptera Acalyptrata from Spain. Part II: Heleomyzidae, Trixoscelididae, Chyromyidae, Curtonotidae, Camillidae, Diastatidae and Campichoetidae. - Graellsia 48: 19-24.

${ }^{7}$ CARles-Tolrá M. 1997: Citas nuevas de dípteros acalípteros para la Península Ibérica (Diptera, Acalyptrata). - Bol. Soc. Entomol. Aragon. 17: 7-10.

${ }^{8}$ CARLes-Tolrá M. 2001a: Algunos dípteros nuevos para Portugal (Insecta, Diptera). — Zool. Baetica 12: 91-100.
${ }^{9}$ CARLES-Tolrá M. 2001b: Nuevos datos sobre dípteros iberobaleares (Díptera: Orthorrhapha y Cyclorrhapha). - Boln. Asoc. Esp. Entomol. 25: 53-95.

${ }^{10}$ Carles-Tolrá M. 2006: Citas nuevas de dípteros para la península Ibérica (Diptera). — Bol. Soc. Entomol. Aragon. 38: 317 319.

${ }^{11}$ Carles-Tolrá M. 2009: Nuevas citas de dípteros para la Península Ibérica y Portugal (Insecta, Diptera). - Bol. Soc. Entomol. Aragon. 45: 443-446.

${ }^{12}$ CArles-Tolrá M. 2011: Some dipterans collected on winter cadavers in La Rioja (Spain) (Diptera: Phoridae, Heleomyzidae and Sphaeroceridae). - Bol. Soc. Entomol. Aragon. 48: 147-150.

${ }^{13}$ Carles-Tolrá M. 2012: The ninth sternite and hypropoct of five species of Oldenbergiella Czerny (Diptera: Heleomyzidae). Bol. Soc. Entomol. Aragon. 50: 477-479.

${ }^{14}$ CARLes-Tolrá M. 2014: Novedades faunísticas y entomosarcosaprófagas de la Región de Murcia, SE de España (Insecta: Diptera). - Bol. R. Soc. Esp. Hist. Nat. (Biol.) 108: 21-35.

${ }^{15}$ Carles-Tolrá M. \& Blasco-Zumeta J. 2001: Estudio comparativo de veintinueve familias de dípteros colectados en un sabinar de Juniperus thurifera en los Monegros. - Bol. Soc. Entomol. Aragon. 29: 49-64.

${ }^{17}$ Carles-Tolrá M. \& PÁez A.V. 2010: Nuevos datos dipterológicos del Parque Natural de los Alcornocales (Cádiz, España) (Insecta, Diptera). — Bol. Soc. Entomol. Aragon. 47: 369-371.

${ }^{18}$ Carles-Tolrá M. \& Prado e Castro C. 2011: Some dipterans collected on pig carcasses in Portugal (Diptera: Carnidae, Heleomyzidae, Lauxaniidae and Sphaeroceridae). - Bol. Soc. Entomol. Aragon. 48: 233-236.

${ }^{19}$ Carles-Tolrá M. \& Pujade-Villar J. 2003: Citas nuevas de dipteros para la Península Ibérica y Andorra (Diptera: Orthorrhapha y Cyclorrhapha). — Bol. Soc. Entomol. Aragon. 32: 169-177.

${ }^{16}$ Carles-Tolrá M., Garanto O. \& Checa J.I. 1993: Nuevas citas y datos de dípteros acalípteros para España (Diptera: Acalyptrata). - Sessió Conjunta Entomol. ICHN-SCL 7: 83-89.

${ }^{20}$ Carles-Tolrá M., Romera C.G. \& Barrientos J.A. 2000: Dípteros capturados en un hayedo del Montseny mediante interceptores de vuelo (Diptera, Acalyptrata). - Boln. Asoc. Esp. Entomol. 24: 141-160.

Carles-Tolrá M., Compaired F. \& Blasco J. 2011: Thyreophora cynophila (Panzer), Centrophlebomyia furcata (Fabricius) and other dipterans associated to winter carcasses (Insecta: Diptera). - Bol. Soc. Entomol. Aragon. 48: 217-220.

${ }^{21}$ Ceianu I., Martinek V. \& Ghizdavu L. 1991: Contribution to the knowledge of families Lauxaniidae and Heleomyzidae (Diptera, Acalyptrata) in Romania. - Trav. Mus. Natn. Hist. Nat. "Grigore Antipa" 31: 85-112.

Christian E. \& Spötl C. 2010: Karst geology and cave fauna of Austria: a concise review. - Int. J. Spel. 39: 71-90.

${ }^{22}$ Ciampolini M. \& Süss L. 1983: Nuovi reperti sulla mosca dell'aglio, Suillia univittata (von Roser) (Diptera, Heleomyzidae). - Boll. Zool. Agric. Bachic. (Ser. II) 17: 19-38.

${ }^{23}$ Collin J.E. 1943: The British species of Heleomyzidae (Diptera). - Entomol. Mon. Mag. 79: 234-251.

${ }^{24}$ CZerny L. 1924: Monographie der Heleomyziden. - Abh. Zool.Bot. Ges. Wien 15: 1-166.

${ }^{25}$ Czerny L. 1930: Dipteren auf Schnee und in Höhlen. - Mitt. K. Naturwiss. Inst. Sofia 3: 113-118.

${ }^{26}$ Dainat H., Delage A. \& Lauraire M. 1971: Contribution à l'étude des Diptères acalyptères de la région de Montpellier. - Nouv. Rev. Entomol. 1: 86-106. 
DurŁo G. 2003: Bioclimatic typology of Jaworzyna Krynicka and valley of Czarny Potok. - Sylwan 8: 76-83 [in Polish, English abstr.].

${ }^{27}$ Dvořáková K., Preisler J. \& RoháčeK J. 2009: Heleomyzidae. In Roháček J. \& Ševčík J. (eds): Diptera of the Pol'ana Protected Landscape Area - Biosphere Reserve (Central Slovakia). State Nature Conservancy of the Slovak Republic, Administration of the Protected Landscape Area - Biosphere Reserve Pol'ana, Zvolen, pp. 254-259.

${ }^{28}$ Dvořáková-Marsová K., MartineK V., Barták M. \& KubíK Š. 2006: Heleomyzidae. In Barták M. \& Kubík Š. (eds). Diptera of Podyji National Park and Its Environs. Czech Agricultural University, Prague, pp. 325-331.

${ }^{29}$ EmLey D.V. 1992: Staffordshire Flies - A Provisional List. 2nd $E d$. Staffordshire Biological Recording Scheme Publication, No. $15,142 \mathrm{pp}$.

ERHARD C. \& Spötl C. 2010: Karst geology and cave fauna of Austria: a concise review. - Int. J. Speleol. 39: 71-90.

${ }^{30}$ Frey R. 1913: Beitrag zur Kenntniss der Arthropodenfauna im Winter. - Mem. Soc. Faun. Flor. Fenn. 39: 1-45.

${ }^{31}$ Frey R. 1941: Diptera Brachycera (excl. Muscidae, Tachinidae). In Enumeratio Insectorum Fenniae, VI, Diptera. Helsingin Hyönteisvaihtoyhdistys, Helsinki, 61 pp.

GiıKa W., SoszyŃSKa-Maj A. \& PAasivirTa L. 2013: The peculiar winter-active midge Diamesa starmachi (Diptera: Chironomidae). - Pol. J. Entomol. 82: 201-211.

${ }^{32}$ Gorodkov K.B. 1962a: Revision of the Palaearctic species of the genus Leria R.-D. (Diptera, Helomyzidae). - Entomol. Obozr. 41: 643-671 [in Russian].

${ }^{33}$ Gorodkov K.B. 1962b: Helomyzidae, Fauna Leningradskoi Oblasti i Karelii. — Trudy Zool. Inst. Leningr. 31: 276-279.

Gorodkov K.B. 1972: A system of Holarctic Helomyzidae (Diptera, Acalyptratae). In: Lectures at the XXIII Annual Readings in Memory of N.A. Kholodkovsky, 2 april 1970. Nauka, Leningrad, pp. 50-92 [in Russian].

Gorodkov K.B. 1984: Family Heleomyzidae. In Soós A. \& Papp L. (eds): Catalogue of Palaearctic Diptera, 10. Elsevier Science Publishers, Amsterdam, and Akadémiai Kiadó, Budapest, pp. 15-45.

${ }^{34}$ HaCKMAN W. 1963: Studies on the dipterous fauna in burrows of voles (Microtus, Clethrionomys) in Finland. - Acta Zool. Fenn. 102: 1-64.

${ }^{35}$ HaCKMAN W. 1967: On Diptera in small mammal burrows in Northern Europe and Southern Spain. - Notul. Entomol. 47: $1-14$.

HAgvar S. 1971: Field observations on the ecology of a snow insect, Chionea araneoides Dalm. (Dipt., Tipulidae). — Norsk Entomol. Tidsskr. 18: 33-37.

HÅgVar S. 1976: Phenology of egg development and egglaying in a winter-active insect, Chionea araneoides Dalm. (Dipt., Tipulidae). - Norw. J. Entomol. 23: 193-195.

HÅgVar S. 2001: Occurrence and migration on snow, and phenology of egg-laying in the winter-active insect Boreus sp. (Mecoptera). - Norw. J. Entomol. 48: 51-60.

HÅgVar S. 2007: Why do some Psylloidea and Heteroptera occur regularly on snow? - Norw. J. Entomol. 54: 3-9.

HÅGVAR S. 2010: A review of Fennoscandian arthropods living on and in snow. - Eur. J. Entomol. 107: 281-298.

HÅgVar S. \& Aakra K. 2006: Spiders active on snow in Southern Norway. - Norw. J. Entomol. 53: 71-82.

${ }^{36}$ HÅgvar S. \& Greve L. 2003: Winter active flies (Diptera, Brachycera) recorded on snow - a long-term study in south Norway. — Stud. Dipterol. 10: 401-421.
HÅgVar S. \& KRZEmińSKa E. 2008: Contribution to the winter phenology of Trichoceridae (Diptera) in snow-covered southern Norway. - Stud. Dipterol. 14: 271-283.

Herrmann S.J., Sublette J.E. \& Sublette M.F. 1987: Midwinter emergence of Diamesa leona Roback in the upper Arkansas River, Colorado, with notes on other diamesines (Diptera: Chironomidae). - Entomol. Scand. 29 (Suppl.): 309-322.

ITÄMIES J. \& LiNDGREN E. 1989: What food is there available for shrews during the winter? - Aquilo (Zool.) 24: 33-49.

${ }^{37}$ JANVIER H. 1963: La mouche de la truffe (Helomyza tuberiperda Rondani) (Dipt., Helomyzidae). — Bull. Soc. Entomol. Fr. 68: 140-147.

JASKUŁA R. \& SoszyŃSKA-MAJ A. 2011: What do we know about winter active ground beetles (Coleoptera, Carabidae) in Central and Northern Europe? - ZooKeys 100: 517-532.

JefFerson G.T. 1983: The threshold fauna. A neglected area of British cave biology. - Stud. Speleol. 4: 53-58.

Jonsson B. \& SANDLUND O.T. 1975: Notes on winter activity of two Diamesa species (Dipt., Chironomidae) from Voss, Norway. - Norw. J. Entomol. 22: 1-6.

Juggins S. 2007: Software for Ecological and Palaeoecological Data Analysis and Visualisation. User Guide Version 1.5. University of Newcastle, Newcastle upon Tyne, $73 \mathrm{pp}$.

KAHANPÄÄ J. 2014: Checklist of the fly families Chyromyidae and Heleomyzidae (Diptera) of Finland. - ZooKeys 441: 319-324.

KAŇUCH P., JANEČKOVÁ K. \& KRIŠTín A. 2005: Winter diet of the noctule bat Nyctalus noctula. - Folia Zool. 54: 53-60.

KJAERANDSEN J. 1993: Diptera in mines and other cave systems in southern Norway. - Entomol. Fenn. 4: 151-160.

${ }^{38}$ Košel V., Dvořáková K. \& Martinek V. 2006: Faunistic records from the Czech and Slovak Republics. Heleomyzidae. In Kinkorová J. (ed.): Dipterologica Bohemoslovaca, vol. 13. Acta Univ. Carol. (Biol.) 50: 155.

Koshima S. 1984: Novel cold-tolerant insect found in a Himalayan glacier. - Nature 310: 225-227.

Koshima S. 1985: Migration of the Himalayan wingless glacier midge (Diamesa sp.): slope direction assessment by sun-compassed straight walk. - J. Ethol. 3: 93-104.

${ }^{39}$ Kramer H. 1917: Die Musciden der Oberlausitz. - Abh. Naturf. Ges. Görlitz 28: 257-352.

LENCIONI V. 2004: Survival strategies of freshwater insects in cold environments. - J. Limnol. 63: 45-55.

Liszewski S. (ed.) 2001: Monograph of Lodz Province. Łódzkie Towarzystwo Naukowe (Lodz Scientific Society), Łódź, 456 pp. [in Polish].

${ }^{40}$ Lo Giudice G. \& Rivosecchi L. 2010: New records of Heleomyzidae for Italian fauna (Diptera). — Fragm. Entomol. 42: 349-359.

${ }^{41}$ Lo Giudice G. \& Woźnica A.J. 2013: An updated checklist of the Italian Heleomyzidae (Diptera: Sphaeroceroidea). Genus 24: 439-458.

${ }^{42}$ Martinek V. 1972: Suillia lurida (Meigen) and Suillia univittata (von Roser) (Diptera, Heleomyzidae), two different Central European species. - Sbor. Jihočes. Mus. Čes. Buděj. (Přirr. Vědy) 12 (Suppl. 2): 95-102.

${ }^{43}$ Martinek V. 1980: New or rare species of some families of Diptera, Acalyptrata in the fauna of the ČSSR. - Acta Univ. Carol. (Biol.) 1977: 343-351.

${ }^{44}$ MartineK V. 1987: Survey of species of the family Heleomyzidae (Diptera - Acalyptrata) in collections of the Entomological department of the National Museum in Prague. - Čas. Nár. Muz. (Přir. vědy) 156: 36-42.

${ }^{45}$ Martinek V. 1997: The newest finds of some species of the group Acalyptrata (Diptera) in the territory of the Czech and 
Slovak Republics. - Folia Fac. Sci. Nat. Univ. Masar. Brun. (Biol.) 95: 111-114.

${ }^{46}$ Martinek V. \& Mocek B. 1995: Species of some families of Diptera - Acalyptrata in insect collection of the Regional museum at Hradec Králové. - Acta Mus. Reginaehradec. (A) 24: 21-60 [in Czech].

Meigen J.W. 1830: Systematische Beschreibung der bekannten europäischen zweiflügeligen Insekten, T. 6. Schutz, Hamm, IV $+401 \mathrm{pp}$.

Müller A. 1924: Dipterologische Mitteilungen. - Verh. Zool.Bot. Ges. Wien 73(1923): 51-111.

Oliver D.R. 1968: Adaptations of Arctic Chironomidae. - Ann. Zool. Fenn. 5: 115-118.

Østbye E. \& LAURITZEN S. 2013: A checklist of invertebrates from Norwegian caves and mines. - Faun. Norveg. 33: 35-51.

Østbye E., Lauritzen S.E., Fjellberg A., Hauge E., Leinaas H.P., Ottesen P. \& Solhøy T. 1987: Invertebrates of Norwegian caves I. Gastropoda, Oligochaeta, Araneae, Acari, Amphipoda, Collembola, Coleoptera, Lepidoptera and Diptera. Faun. Norveg. (A) 8: 43-64.

${ }^{47}$ PAPP L. 1980: Three new species of Helomyzidae (Diptera) from Hungary. - Acta Zool. Acad. Sci. Hung. 26: 211-221.

${ }^{48}$ PAPP L. 1981: 54. family: Heleomyzidae. In Soós A. (ed.): Fauna Hungariae 15(5). Akadémiai Kiadó, Budapest, pp. 1-77 [in Hungarian].

${ }^{49}$ PAPP L. 1983: Anisopodidae, Trichoceridae, Bibionidae, Scatopsidae, Chamaemyiidae, Heleomyzidae, Ephydridae, Spheroceridae, Drosophilidae and Agromyzidae (Diptera) of the Hortobagy. In Mahunka S. (ed.): The Fauna of the Hortobagy National Park. Vol. 2. Akadémiai Kiadó, Budapest, pp. 241267.

${ }^{50}$ PAPP L. 2007: Further Diptera species new for Hungary. Folia Entomol. Hung. 68: 111-122.

${ }^{51}$ PAPP L. 2009: Additions to the Diptera fauna of Hungary. Folia Entomol. Hung. 70: 225-242.

${ }^{52}$ PAPP L. 2010: New records of Heleomyzidae (Diptera) with description of a new genus and two new species. - Folia Entomol. Hung. 71: 203-212.

${ }^{53}$ PAPP L. \& CARLES-Tolrá M. 1994: A revision of the West Palaearctic species of Schroederella Enderlein (Diptera: Heleomyzidae). - Folia Entomol. Hung. 55: 321-334.

${ }^{54}$ PAPP L. \& WoźNICA A. 1993: A revision of the Palearctic species of Gymnomus Loew (Diptera: Heleomyzidae). - Acta Zool. Hung. 39: 175-210.

${ }^{55}$ Pavlov A.V. 2006: About structures of species and conditions of collection of Dipterans from snow in biotopes of Northern Meshchera (Vladimir Area). - Eversmannnia 6: 56-61 [in Russian, English abstr.]

Pernetta J.C. 1977: Anatomical and behavioural specialisation of shrews in relation to their diet. - Can. J. Zool. 55: 1442 1453.

${ }^{56}$ Preisler J. \& RoháčEK J. 2012: New faunistic records of Heleomyzidae (Diptera) from the Czech Republic and Slovakia, and notes on the distribution of three rare Suillia species. - Čas. Slez. Zem. Muz. Opava (A) 61: 85-90.

RANDOLPH J.C. 1973: Ecological energetics of a homeothermic predator, the short-tailed shrew. - Ecology 54: 1166-1187.

${ }^{57}$ RоHÁČEK J. 1997: Borboropsis and Oldenbergiella (Diptera, Heleomyzidae) in the Czech and Slovak Republics. Faunistic records and notes on their biology. - Folia Fac. Sci. Nat. Univ. Masar. Brun. (Biol.) 95: 145-147.

RoNDANI C. 1867: Scatophaginae Italicae collectae distinctae et in ordinem dispositae. Dipterologiae Italicae prodromus. Pars VII, Fasc. I. - Atti Soc. Ital. Sci. Nat. 10: 85-135.
${ }^{58}$ Schmitz H. 1917: Zur Kenntnis der Heleomyziden von Holländisch Limburg. - Jaarb. Natuur. Genoot. Limburg 1917: 117-131.

${ }^{59}$ SÉGuY E. 1934: Diptères (Brachyceres) (Muscidae, Acalypterae et Scatophagidae). Faune de France, Vol. 28. Lechevalier, Paris, $832 \mathrm{pp}$.

${ }^{60}$ SKIDMORE P. 1962: Notes on the Helomyzidae of Lancashire and Cheshire, including records from other parts of North West England. 2. Sub-family Leriinae. - Entomologist 95: 226-236.

${ }^{61}$ SKidMORE P. 1966: The biology of Scoliocentra villosa (Mg.) (Diptera, Heleomyzidae). - Entomol. Mon. Mag. 102: 94-98.

SøмmE L. \& ØsтвYE E. 1969: Cold-hardiness in some winter active insects. - Norsk Entomol. Tidsskr. 16: 45-48.

SosZyŃSKA A. 2004: The influence of environmental factors on the supranivean activity of Diptera in Central Poland. - Eur. J. Entomol. 101: 481-489.

SOSZYŃSKA A. \& DURSKA E. 2002: Cold-adapted scuttle-flies species of Triphleba Rondani (Diptera: Phoridae). - Ann. Zool. 52: 279-283.

SosZYŃSKA-MAJ A. 2008: The significance of forest complexes for preservation of snow fauna diversity in Lodz. In Indykiewicz P., Jerzyk L. \& Barczak T. (eds): Urban fauna. Protection of the biodiversity in cities. Studio Artystyczno Reklamowe "Pomorze" (Artistic and Advertising Agency "Pomerania"), Bydgoszcz, pp. 78-82 [in Polish, English abstr.].

SoszyŃSKA-MAJ A. \& Buszko J. 2011: Lepidoptera recorded on snow in Central Poland. - Entomol. Fenn. 22: 21-28.

SOSZYŃSKA-MAJ A. \& JASKUŁA R. 2013: Winter activity of earwigs with special focus on the phenology of Chelidura guentheri (Galvagni, 1994) (Dermaptera: Forficulidae). - N. West. J. Zool. 9: 239-244.

${ }^{62}$ Soszyńska-MaJ A. \& Woźnica A.J. 2012: Comments on the biology, systematics and distribution of Scoliocentra (Leriola) nigrinervis (Wahlgren, 1918) in Poland and Europe (Diptera: Heleomyzidae). - Dipteron, Bull. Dipt. Sec. Pol. Entomol. Soc. 28: 23-28.

SoszyŃSKa-Maj A., PaAsivirta L. \& GiŁKa W. 2015: Why on the snow? Winter emergence strategies of snow-active Chironomidae (Diptera) in Poland. — Insect Sci., doi: 10.1111/17447917.12223, $17 \mathrm{pp}$.

${ }^{63}$ Stackelberg A.A. 1970: 83. family Anthomyzidae. In BeiBienko G.Ya. (ed.): Key to the Insects of the European Part of the USSR. Vol. 5, Pt. 2. Nauka, Leningrad, pp. 326-329 [in Russian].

StatSoft Inc. 2011: STATISTICA (Data Analysis Software System). Version 10. URL: www.statsoft.com.

${ }^{64}$ STORA R. 1958: Über einige Helomyziden-Arten (Diptera) Finnlands. - Notul. Entomol. 38: 61-63.

SVEnsson S.A. 1966: Studies on the biology of certain winter active insects. - Norsk Entomol. Tidsskr. 13: 335-338 [in Swedish].

${ }^{65}$ TAHVONEN E. 1942: Beobachtungen über Winterinsekten. Ann. Entomol. Fenn. 8: 203-214.

${ }^{66}$ VAN DeR Weele R. 1996: Some notes on Heleomyzinae collected in Hungary (Diptera: Heleomyzidae). — Folia Entomol. Hung. 57: 291-293.

${ }^{67}$ Von DER DunK K. 2006: Zweiflügler aus Bayern XXIV (Diptera: Heleomyzidae, Trixoscelididae). - Entomofauna, $Z$. Entomol. 27: 177-184.

von Roser C. 1840: Erster Nachtrag zu den im Jahre 1834 bekannt gemachten Verzeichnissen in Württemberg vorkommender zweiflügliger Insekten. - Correspondenzbl. Württemb. Landwirtsch. Ver. (Stuttgart) (N.S.) 1: 49-64. 
${ }^{6}$ W AHLGREN E. 1918: Zur Kenntnis schwedischer Dipteren III. Entomol. Tidskr. 39: 1-9.

Weber D. \& Weber G. 2013: Heleomyzidae. In Weber D. (ed.): Die Höhlenfauna Luxemburgs. - Ferrantia 69: 373-381.

Williams C.M., Salter L. \& Jones G. 2011: The winter diet of the lesser horseshoe bat (Rhonolophus hipposeideros) in Britain and Ireland. - Hystrix, It. J. Mamm. 22: 159-166.

${ }^{69}$ Withers P. 2010: Annotated list of Heleomyzidae and allied families (Diptera) of Sweden. - Dipt. Digest 17: 171-179.

Woźnica A.J. 1996: Systematic Revision of Palearctic Heleomyzids from the Genus Scoliocentra Loew (Diptera: Heleomyzidae). PhD thesis, University of Gdańsk, Gdynia, 122 pp. [in Polish].

WoźnICA A.J. 2007: Błotniszkowate (Heleomyzidae). In Bogdanowicz W., Chudzicka I., Pilipiuk I. \& Skibińska E. (eds): Fauna Polski, Vol. 2. Muzeum i Instytut Zoologii PAN, Warszawa, pp. 211-213.

Woźnica A.J. 2008: Heleomyzidae. In Ziegler J. (ed.): Diptera Stelviana. A dipterological perspective on a changing alpine landscape, vol. 1. — Studia Dipterol. Suppl. 16: 178-184.
WoźNICA A.J. 2011: Taxonomic notes on the genus Gymnomus Loew, with a description of a new species from Morocco (Diptera: Heleomyzidae). — Pol. J. Entomol. 80: 579-586.

WoźNICA A.J. 2013: Fauna Europaea: Heleomyzidae. In Pape T. \& Beuk P. (eds): Fauna Europaea: Brachycera, Diptera. Fauna Europaea version 2.6.2. URL: http://www.faunaeur.org. ${ }^{70}$ Woźnica A.J. \& KLASA A. 2010: Heleomyzid flies of the Ojców National Park, with notes on Suillia lineitergum (Pandellé, 1901) - a species new to the fauna of Poland (Diptera: Heleomyzidae). — Fragm. Faun. 52[2009]: 181-190.

Woźnica A.J. \& SoszyńsKa-MaJ A. (in press): Suillia cepelaki Martinek, 1985 a new species for the Polish fauna with comments on the Suillia lurida species group (Diptera, Heleomyzidae). - Pol. J. Entomol.

${ }^{71}$ ZAIKA M.I., WoźNICA A. \& KoRNEEV V.A. 2010: The first record of Orbellia hiemalis (Diptera, Heleomyzidae) for the fauna of Ukraine. — Vest. Zool. 44: 508-508.

Received August 26, 2015; revised and accepted January 27, 2016 Published online March 24, 2016 